\title{
WINDFALLS, WEALTH, AND THE TRANSITION TO SELF-EMPLOYMENT
}

YANNIS GEORGELIS, JOHN G. SESSIONS. NICHOLAS TSITSIANIS

THIS ARTICLE HAS BEEN PUBLISHED IN:
SM ALL BUSINESS ECONOM ICS JOURNAL (2005), Vol. 25, pp. 407-428

YANNIS GEORGELLIS, NICHOLAS TSITSIANIS

Department of Economics and Finance

Brunel University

Uxbridge,

Middlesex UB8 3PH

England

\section{JOHN G. SESSIONS}

Department of Economics and International Development

University of Bath

Claverton Down

Bath BA2 7AY

England

\begin{abstract}
We examine the transition to, and survival in, self-employment among a sample of British workers. We find evidence of capital constrains, with wealthier individuals being more likely to transit ceteris paribus. Windfall gains raise the probability of transition at a decreasing rate gains or more than $£ 20000-£ 22000$ reduce the probability of transition - and larger gains reduce the probability of transition amongst relatively wealthier respondents. We also find peculiarities in the effects of particular types of windfall; redundancy payments and inheritances raise the probability of transition, whilst lottery wins reduce the probability of (especially male) transitions. In contrast, inheritances (lottery wins) hinder (augment) self-employment survival.
\end{abstract}

KEY WORDS: Self-employment, transitions, windfalls

JEL CLASSIFICATION: J0; J5, J23

\section{INTRODUCTION}

Governments around the world are turning to self-employment as a panacea for the problems of unemployment and poverty ${ }^{1}$. But although the self-employed are a growing proportion of the workforce in many counties, evidence suggests that many more individuals are frustrated in their desire to pursue entrepreneurship. According to the International Social Survey Programme (1989) 63\% of Americans, 48\% of Britons, and $49 \%$ of Germans expressed a desire to become self-employed, although in none of these countries did the actual share of self-employment exceed $15 \%{ }^{2}$.

Some researchers have attributed the shortfall to capital constraints that limit the access of budding entrepreneurs to external sources of finance, thereby jeopardising both the growth and survivability of their enterprise. Support for this thesis is derived from a number of studies that find the probability of transition to 
self-employment to be significantly lower amongst less wealthy individuals. Indeed, the gap between actual and desired entrepreneurship appears to be greatest in those areas most afflicted by unemployment and poverty, the North of England being a particular case in point (Blanchflower and Oswald 1998).

Using wealth as an explanatory variable in this way is, however, somewhat dubious. There is a distinct possibility that pre-transition wealth is correlated with an individual's ability or 'drive', and that it is this unobserved and omitted factor which is determining the success or otherwise of the transition. With this in mind, attention has turned to the analysis of windfall gains ${ }^{3}$. These are far less likely to be so correlated, being, in the words of Blanchflower and Oswald (1998) and Holtz-Eakin et al. (1994a), about as close to a natural experiment as economists are likely to get in this area.

In this paper we examine data from the British Household Panel Survey (BHPS) to identify factors at time $\mathrm{t}$ ) 1 that play a pivotal role in the transition to, and survival in, self-employment at time $t+1$. We uncover evidence of significant capital constraints. Wealthier individuals are more likely to transit ceteris paribus, whilst windfalls raise the probability of transition non-linearly - gains or more than $£ 20000-£ 22000$ reduce the probability of transition. Moreover, larger windfalls reduce the probability of relatively wealthier respondents making a transition to self-employment. We also find peculiarities in the effects of particular types of windfall. Redundancy payments and inheritances raise the probability of transition, whilst lottery wins reduce the probability of (especially male) transitions. In contrast, inheritances (lottery wins) hinder (augment) selfemployment survival.

Significant gender differences are also apparent. Whilst male and female transitions tend to emanate from amongst the unemployed, females are particularly reluctant to leave paid employment. Further gender differences are evident in terms of education, labour market state tenure and the effect of household income.

The paper is set out as follows: Section 2 provides a brief discussion of previous empirical work on the selfemployment decision. Section 3 describes our data and methodology whilst our results are presented in Section 4. Final comments are collected in Section 5.

\section{BACKGROUND}

The relationship between capital constraints and entrepreneurship is well documented. Potential entrepreneurs will choose to become self-employed if the utility from self-employment exceeds that from paid work. Individuals may be denied access into self-employment if they lack the requisite capital to meet the costs of business start-up, or to provide sufficient collateral to obtain appropriate external funding. An increase in capital will alleviate these constraints and so should increase transitions into self-employment Taylor (2001). The effect of an increase in capital on existing entrepreneurs is not obvious. If the entrepreneur is liquidity constrained, then an increase in capital should enable the enterprise to invest, expand and prosper. If the enterprise is not so undercapitalised, then the increase should have no effect on profitability since the entrepreneur would have no incentive to invest the funds in the enterprise. Indeed, an increase in capital in this situation may provide such a cushion of financial security that the entrepreneur is tempted to pursue more rewarding activities - the profitability and/or size of the enterprise may diminish, and the entrepreneur might even choose to exit self-employment completely if he now feels that the resources he is currently investing in the business may be better employed elsewhere, or if the utility from an alternative labour market activity exceeds that of self-employment Taylor (2001).

Theoretical work emphasizes insufficient start-up capital and/or access to credit markets as a binding constraint on individuals' choice between paid employment and self-employment (Stiglitz and Weiss 1981, Coate and Tennyson 1992). Such a hypothesis is supported by numerous empirical studies. Meyer (1990), for example, uses cross sectional US data to examine transitions from paid-employment into selfemployment and finds that the incidence of self-employment increases with an individual's net worth. Evans and Leighton (1989) and Evans and Jovanovic (1989), using longitudinal US data, proxy the availability of capital by net family assets and find a concave relationship between these and the transition to selfemployment. Dunn and Holtz-Eakin (2000) uncover longitudinal evidence suggesting that the financial assets of young males exert a small but significant influence on the probability of transition. Studies undertaken for the Australian, British, Canadian, Dutch and Finish labour markets (respectively De Wit and Van Winden 1990; Kidd 1993; Bernhardt 1994; Black et al. 1996 and Johansson 2000) also report that the availability of capital is a significant factor affecting the self-employment decision ${ }^{4}$. Evidence pertaining to the relationship between capital constraints and self-employment survival is less clear-cut. Survey data suggests that availability of capital is certainly a major concern to entrepreneurs (Blanchflower and Oswald 1998), and evidence from the US (Jovanovic, 1982; Bates, (1990), Holtz-Eakin et al. 1994a; Fairlie, 1999) and the UK 
(Taylor 1999) suggests that self-employment survival is positively related to the endowment of capital. Some discordance, however, has been voiced. Meyer (1990), for example, finds that an individual's net worth impacts insignificantly on self-employment survival in the US, whilst Cressy (1996) argues that the correlation between financial capital and survival in the UK is spurious, the former playing little if any role once one controls for even the most basic individual characteristics such as age and education ${ }^{5}$. Recent research in this area has exhibited a growing awareness of the endogeneity problem inherent in using pretransition wealth and attention has shifted to unanticipated "windfall" payments as a predictor of selfemployment entry and survival - see Table I. Such payments are unlikely to be correlated with omitted factors that may themselves be affecting the probability of transition - ambitious and "driven" individuals, for example, may be both wealthier and more likely to take the plunge into self-employment.

TABLE I

Windfalls - summary of recent empirical evidence

\begin{tabular}{|c|c|c|c|c|c|}
\hline Study & Variable & Effect & Data & Method & Remarks \\
\hline \multirow[t]{2}{*}{ Holtz-Eakin et al. (1993) } & Inheritance & - & US & Logit & $\begin{array}{l}\text { An inheritance reduces (at an } \\
\text { increasing rate) the probability } \\
\text { of being in the labour force. }\end{array}$ \\
\hline & Inheritance-squared & + & & & \\
\hline \multirow[t]{2}{*}{ Holtz-Eakin et al. (1994a) } & Inheritance & + & US & $\begin{array}{l}\text { Multinomial } \\
\text { Logit }\end{array}$ & $\begin{array}{l}\text { Receiving an inheritance in- } \\
\text { creases the probability that an } \\
\text { entrepreneur will stay in busi- } \\
\text { ness. }\end{array}$ \\
\hline & Inheritance includes business & + & & & \\
\hline \multirow[t]{2}{*}{ Holtz-Eakin et al. (1994b) } & Inheritance & + & US & Probit & $\begin{array}{l}\text { Inheritance increases the prob- } \\
\text { a bility of entry into self-em- } \\
\text { ployment from paid } \\
\text { employment. }\end{array}$ \\
\hline & Inheritance*liquid assets & - & & & $\begin{array}{l}\text { The greater the individual } \\
\text { wealth, the smaller the incre- } \\
\text { mental effect of inheritance. }\end{array}$ \\
\hline Lindh and Ohlsson (1996) & Inheritance & + & SWE & Probit & $\begin{array}{l}\text { Inheritances and lottery win- } \\
\text { nings increase (at a decreasing } \\
\text { rate) the probability of self- } \\
\text { employment. }\end{array}$ \\
\hline
\end{tabular}

Blanchflower and Oswald (1998)

Burke et al. (2000)

Taylor (2001)

Burke et al. (2002)
Lottery winnings

Spousal Inheritance

Inheritance

Inheritance-squared Log of Inheritance Inheritance

Inheritance-squared Windfall

Windfall-squa red Inheritance
$-$ None

+ UK Probit

UK Probit

UK Probit

UK Probit
The probability of self-employment depends positively upon whether the individual ever received an inheritance.

The receipt of an inheritance increases (at a decreasing rate) the probability of self-employment.

The receipt of a windfall gain raises the transition into selfemployment

Inheritances increase (at a decreasing rate) the probability of self-employment.

In a number of studies Holtz-Eakin et al. $(1993,1994 a$, b) find that the receipt of a gift or inheritance increases the probability of becoming, and continuing as, an entrepreneur. Moreover, conditional on becoming an entrepreneur, the size of the inheritance increases the amount of capital employed in the business, whilst conditional on survival, the size of the inheritance increased the receipts of the business. In a study of Swedish microdata, Lindh and Ohlsson (1996) find that the probability of self-employment increases by $54 \%$ on receipt of lottery winnings, and by $27 \%$ on receipt of an average-sized inheritance. Contrary to Holtz-Eakin et al. (1993), Swedish lottery winnings and inheritances do not induce individuals to exit the labour force. Somewhat more direct evidence of the relationship between windfalls and the transition to self-employment is available from the multivariate analysis of the National Child Development Survey 
(NCDS) undertaken by Blanchflower and Oswald (1998). The authors here conclude that respondents receiving windfall payments of $£ 5000$ or more were twice as likely to be self-employed as those not receiving an inheritance ceteris paribus. Some caution in interpreting this finding is warranted. Blanchflower and Oswald's analysis was necessarily restricted to respondents under 23 years of age, and the limited labour market experience and capital accumulation of such individuals may be unduly exaggerating the influence of windfall payments.

The NCDS (National Child Development Study) data is also utilised by Burke et al. (2000) whose probit estimates re-affirm Blanchflower and Oswald's (1998) finding that the receipt of a financial gift or inheritance increases at a decreasing rate the estimated probability of self-employment. Specifically, Burke et al. (2000) find that the probability of entering self-employment increases by $6 \%(0.5 \%)$ on receipt of an inheritance worth $£ 75000$ ( $£ 2 \frac{1}{2}$ million). The authors also find that the receipt of an inheritance significantly raises selfemployment income and job creation, the latter reaching a maximum at a gift value of $£ 70000$. In their subsequent study of the same data set, the authors explore the effects of inheritance on the propensity to become and prosper in self-employment across gender (Burke et al. (2002). Their results here suggest that a financial gift or inheritance increases the estimated probability of male (female) self-employment at a constant (decreasing) rate. Inheritances also increase at a decreasing rate the rate of male entrepreneurial job creation and the value of male entrepreneurial enterprises.

A major advance in unravelling the nexus between wealth and self-employment is the study by Taylor (2001). Taylor utilises data from waves $4-6$ of the BHPS to assess the impact of windfalls on selfemployment transitions over the period 1994-1996. He finds that individuals in paid-employment are most likely to receive a windfall, and that these windfalls tend to be higher than those that are received by individuals in other labour market states. Multivariate analysis suggests that the amount and type of the windfall are important predictors of the transition into self-employment. The probability of self-employment peaks at a windfall value of $£ 15000$, with the receipt of a $£ 5000$ windfall almost doubling the probability of becoming self-employed. The type of windfall is crucial - redundancy payments (job-related bonuses) increase (decrease) the probability of transiting into self-employment. It would thus appear that individuals are pushed into self-employment - the loss of a job, and the associated compensation, spurs individuals into self-employment whilst individuals employed in jobs that reward performance are less likely to strike out on their own.

In what follows we extend Taylor's analysis in a number of important ways. First, we augment the data to focus on BHPS transitions over the period 1994-2000. Second, we analyse the transitions of males and females, both collectively and separately. Third, we examine the transitions of employed, unemployed, and non-participating individuals, again both collectively and separately - it may be the case that there are significant heterogeneities in the data generating processes of employed 'insiders' and unemployed 'outsiders', whilst some individuals may enter the labour market directly through self-employment. And fourth, we investigate the interaction between the windfall and the capital position of the individual - although windfalls may encourage entrepreneurial, but liquidity constrained, individuals to transit, they may permit wealthier individuals to by-pass work and move straight to early retirement.

\section{DATA AND METHODOLOGY}

Our data are derived from the BHPS. This is a nationally representative survey of some 5500 private households, comprising some 10,000 individuals, interviewed annually every fall since 1991. Children in the households are interviewed separately once they reach the age of 16, and if any member of a household splits to form a new household, then all adult members of both the original and new households are interviewed annually. By such means, the survey remains broadly representative of the British populace over time.

Our analysis is based on windfall data recorded in waves five (1995), seven (1997), eight (1998), and nine (1999). Having recorded a respondent's labour market status at time t-1, we examine how windfall payments received at time $t$ affect the respondent's recorded labour market status at time $t+1$. We therefore use data on labour market status from waves 4 (1994) to 10 (2000) to identify those individuals who transited into, survived in, or exited from, self-employment in the year following the receipt of a windfall. We restrict our attention to men and women aged between 18 and 60, thereby ensuring that the sampled members are always of working age, and are not apt to the receipt of lump sum payments that are associated with retirement at the usual age. We exclude members of the armed forces but, to account for the possibility that 
some individuals enter the labour market directly through self-employment, we include non-participants. The question concerning windfall payments in survey year $t$ is as follows: "Since September 1st $t$ - 1 have you received any payments, or payments in kind, from anything listed on this card? If answering Yes, respondents were subsequently asked: (i) Which ones? And (ii) About how much did in total did you receive/was this worth?" The list of possible payments in waves five seven, eight and nine includes a life insurance policy, a lump sum pension payout, a personal accidental claim, a redundancy payment, an inheritance or bequest (including inherited property), a win on the football pools, national lottery or other sort of gambling, or anything else ${ }^{6}$. In wave five the list also includes an annual/seasonal bonus from employment, whilst in wave seven it includes a lump sum from a building society conversion. Given the specificity of these questions we incorporated them into the "anything else" category. Moreover, since receipts from life insurance policies and pension payouts are, to some extent, predictable, they may be endogenous and we follow Taylor (2001) in excluding them from the analysis ${ }^{7}$.

We define individuals as either employed or self-employed according to the two questions relating to employment status in the BHPS: First, there is a self-reported employment status question vis. "Are you an employee or self-employed?"; second, there is a question relating to the respondent's current labour force status - vis. "Please look at this card and tell me which best describes your current situation? (List: selfemployed, in paid employment, unemployed, retired, family care, full-time student, long-term sick/disabled, on maternity leave, on a government training scheme)". We exclude part-time workers by restricting our attention to those respondents who report themselves as working more than 30 hours per week. A small number of individuals who gave inconsistent answers across questions and/or waves (e.g. reporting themselves as both employed and self-employed) were also excluded from the analysis ${ }^{8}$. Finally, because labour market status is recorded over a 24-month interval (i.e. at time $t$ and then again at time $t+2$ ), respondents who experienced a self-employment spell within the two observation points are necessarily excluded because it is not clear whether their spell preceded or succeeded the receipt of a windfall. Our potential pool consists of $9597(12,216)$ male (female) respondents. Of these, some $38.9 \%$ of male, $32.1 \%$ of female, and $35.1 \%$ of all respondents received some form of windfall. The distribution of windfall gains by labour market status and gender and by windfall type and gender, are set out in Tables II and III.

It is apparent from Table II that $87.5 \%$ of male beneficiaries were in employment, $4.8 \%$ were unemployed, and $7.7 \%$ were out of the labour force. The respective figures for female beneficiaries were $74.8 \%, 2.6 \%$ and $22.6 \%$ respectively. Males have a greater propensity $(38.9 \%)$ of receiving a windfall than females $(32.1 \%)$, and male beneficiaries tend to receive higher amounts than do female beneficiaries. There is substantial variation in the size of the windfalls received $-43.5 \%$ of receipts are for less than $£ 100$ and $36.2 \%$ are for more than $£ 1000$. The average amount received across all individuals (beneficiaries) is $£ 1167$ ( 3300 ), with employees enjoying both a relatively higher probability and size of receipt. The most common type of windfall payment is a lottery winning, received by 52.1 and $51.4 \%$ of males and female recipients respectively. The corresponding figures for inheritances and/or bequests were just 5.3 and $8.1 \%$ respectively ${ }^{9}$. We observe a total of 659 transitions into self-employment in our data, implying a transition rate of $3.02 \%$. The transitions are decomposed in Table IV where a number of interesting features are evident. First, less than one half of the total transitions were made by beneficiaries of a windfall. Second, irrespective of whether a windfall was actually received, the majority of transitions were made by individuals already in employment - indeed, none of the 1997-1998 female transitions emanated from unemployment. And third, although transitions from employment are relatively evenly distributed across males $(55.7 \%)$ and females $(44.3 \%)$, males dominate transitions from unemployment $(78.5 \%)$ whilst females dominate transitions from out of the labour force $(77.9 \%)^{10}$.

It is apparent then that not everyone who receives a windfall will enter self-employment, nor that everyone who enters self-employment will have received a windfall. It is likely that individuals require at least two things to become entrepreneurs - entrepreneurial acumen and capital. Individuals lacking in the former are unlikely to become (or remain) self-employed irrespective of their wealth; indeed, a windfall gain by such an individual may encourage them to withdraw from the labour market either partially or completely. An "entrepreneurial" individual may lack the necessary capital for self-employment, in which case a windfall gain may encourage transition. Even in this case, however, a sufficiently large gain may entice the individual to by-pass work and move straight to early retirement.

In the empirical analysis that follows we attempt to cast some light on these issues. We attempt to control, as far as our data permit, for entrepreneurial acumen and drive by employing an extensive battery of demographic and personal characteristics. We also focus on the size of the windfall, the size of the respondent's pre-transition wealth, and the interaction between the two. 
TABLE II

Windfall (WF) receipts by labour market status \& gender

\begin{tabular}{|c|c|c|c|c|c|c|c|c|c|c|c|c|c|c|c|c|c|c|c|c|}
\hline \multirow[t]{2}{*}{ Males } & \multicolumn{5}{|c|}{ Employed } & \multicolumn{5}{|c|}{ Unemployed } & \multicolumn{5}{|c|}{ Out of labour force } & \multicolumn{5}{|c|}{ Aggregate Figures } \\
\hline & 1995 & 1997 & 1998 & 1999 & Total & 1995 & 1997 & 1998 & 1999 & Total & 1995 & 1997 & 1998 & 1999 & Total & 1995 & 1997 & $1998 \quad 1$ & 1999 & Total \\
\hline \multicolumn{21}{|l|}{ Males } \\
\hline$<\notin 100$ & 400 & 230 & 380 & 312 & 1322 & 44 & 19 & 24 & 8 & 95 & 50 & 27 & 37 & 29 & 143 & 494 & 276 & 4413 & 349 & 1560 \\
\hline 499 & 149 & 100 & 101 & 99 & 449 & 6 & 2 & 6 & 5 & 19 & 8 & 0 & 15 & 8 & 40 & 163 & 111 & 1221 & 112 & 508 \\
\hline $10-t y\}$ & 79 & 65 & 38 & 34 & 216 & 3 & 1 & 4 & 2 & $10 \%$ & 2 & 3 & 3 & 1 & 9 & 84 & 69 & 45 & 37 & 235 \\
\hline$t 1000-6$ & 161 & 479 & 135 & 104 & 879 & 7 & 22 & 4 & 1 & 34 & 9 & 32 & 13 & 11 & 65 & 177 & $533 \quad 1$ & $152 \quad 1$ & 116 & 978 \\
\hline 99 & 2 & 52 & 38 & 39 & 155 & 3 & 4 & 3 & 1 & 11 & 2 & 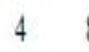 & 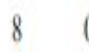 & . & 14 & 31 & 60 & 49 & 40 & 180 \\
\hline t10 & 5 & 58 & 66 & 65 & 241 & 3 & 3 & 3 & 2 & 11 & 6 & 5 & 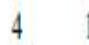 & 1 & 16 & 01 & 66 & 73 & 68 & 268 \\
\hline In rea & 86 & 984 & 758 & 653 & 3262 & 66 & 51 & 44 & 19 & 180 & 77 & 80 & 80 & 50 & 287 & 1010 & 1115 & 8827 & 22 & 3729 \\
\hline lot 1 & 910 & 874 & 1316 & 1458 & 4558 & 168 & 134 & 122 & $120:$ & 544 & 154 & 155 & 234 & 223 & 766 & 1232 & 1163 & 16721 & 1801 & 5868 \\
\hline Sub total & 1777 & 1858 & 2074 & 2111 & 7820 & 234 & 185 & 166 & 139 & 724 & 231 & 235 & 314 & 273 & 1053 & 2242 & 2278 & 25542 & 2523 & 9597 \\
\hline $\begin{array}{l}\text { Probability of } \\
\text { receiving windfall }\end{array}$ & 48.79 & 52.96 & 36.55 & 30.93 & 41.71 & 28.21 & 27.57 & 26.51 & 13.67 & 24.86 & 33.33 & 34.04 & 25.48 & 18.32 & 27.26 & 45.05 & 48.95 & 34.532 & 28.62 & 38.86 \\
\hline \multicolumn{21}{|l|}{ Females } \\
\hline 400 & 43 & 212 & 373 & 235 & 1258 & 23 & 8 & 11 & 6 & 48 & 185 & 94 & 109 & 75 & 463 & 646 & 314 & 493 & 316 & 1769 \\
\hline 400 & 158 & 81 & 84 & 81 & 404 & 5 & 1 & 3 & 5 & 14 & 29 & 28 & 25 & 21 & 103 & 192 & 110 & 112 & 107 & 521 \\
\hline 0.6 & 78 & 84 & 32 & 32 & 226 & 1 & 1 & 1 & 1 & 4 & 10 & 24 & 11 & 10 & 55 & 89 & 109 & 44 & 43 & 285 \\
\hline & 112 & 414 & 115 & 105 & 746 & 7 & 11 & 7 & 4 & 29 & 32 & 95 & 32 & 29 & 188 & 151 & 520 & $154 \quad 1$ & 138 & 963 \\
\hline$-\ell^{29999}$ & 31 & 34 & 32 & 38 & 135 & 1 & 1 & 1 & 1 & 4 & 4 & 12 & 10 & 5 & 31 & 36 & 47 & $43 \quad 4$ & 44 & 170 \\
\hline$>£ 10000$ & 34 & 44 & 48 & 38 & 164 & 1 & 0 & 1 & 2 & 4 & 13 & 12 & 11 & 9 & 45 & 48 & 56 & 60 & 49 & 213 \\
\hline In receipt & 851 & 869 & 684 & 529 & 2933 & 38 & 22 & 24 & 19 & 103 & 273 & 265 & 198 & 149 & 885 & 1162 & 1156 & 9066 & 697 & 3921 \\
\hline Not in rece & 1014 & 1116 & 1541 & 1685 & 5356 & 70 & 81 & 78 & 78 & $307:$ & 553 & 554 & 762 & 763 & 2632 & 1637 & 1751 & 23812 & 2526 & 8295 \\
\hline Sub tota & 1865 & 1985 & 2225 & 2214 & 8289 & 108 & 103 & 102 & 97 & 410 & 826 & 819 & 960 & 912 & 3517 & 2799 & 2907 : & 32873 & 3223 & 12216 \\
\hline $\begin{array}{l}\text { Probability of } \\
\text { receiving windfall }\end{array}$ & 45.63 & 43.78 & 30.74 & 23.89 & 35.38 & 35.19 & 21.36 & 23.53 & 19.59 & 25.12 & 33.05 & 32.36 & 20.63 & 16.34 & 25.16 & 41.51 & 39.77 & 27.562 & 21.63 & 32.10 \\
\hline Totals & 3642 & 3843 & 4299 & 4325 & 16109 & 342 & 288 & 268 & 236 & 1134 & 1057 & 1054 & 1274 & 1185 & 4570 & 5041 & 5185 & 58415 & 5746 & 21813 \\
\hline
\end{tabular}


TABLE III

Distribution of windfall types by year and gender

\begin{tabular}{|c|c|c|c|c|c|c|c|c|c|c|c|}
\hline & \multicolumn{5}{|l|}{ Males } & \multicolumn{5}{|l|}{ Females } & \multirow[t]{2}{*}{ Total } \\
\hline & 1995 & 1997 & 1998 & 1999 & Sub-Total & 1995 & 1997 & 1998 & 1999 & Sub-Total & \\
\hline \multicolumn{12}{|l|}{ Life Insurance } \\
\hline Number & 66 & 68 & 83 & 79 & 296 & 101 & 91 & 74 & 74 & 340 & 636 \\
\hline Mean $(f)$ & 6075.56 & 6423.17 & 8654.60 & 8008.15 & - & 3492.57 & 5412.95 & 9600.19 & 3420.65 & - & \\
\hline Median (f) & 2000.00 & 2500 & 3538.5 & 3600 & - & 1150 & 2280 & 1700 & 1900 & - & \\
\hline \multicolumn{12}{|l|}{ Pension Payout } \\
\hline Number & 22 & 26 & 24 & 26 & 98 & 23 & 24 & 20 & 27 & 94 & 192 \\
\hline Mean $(f)$ & 33754.8 & 29023.43 & 37051.82 & 22013.64 & - & 16009.13 & 15026.13 & 31365.84 & 22646 & - & \\
\hline \multicolumn{12}{|c|}{ Accident Claim } \\
\hline Number & 34 & 31 & 32 & 35 & 132 & 16 & 17 & 23 & 29 & 85 & 217 \\
\hline Mean (f) & 3534.38 & 3968.8 & 2625.90 & 3882.88 & - & 5362.86 & 4645.65 & 3790.04 & 4981.90 & - & \\
\hline $\begin{array}{l}\text { Median }(f) \\
\text { Redundancy }\end{array}$ & 2030 & 2950 & 1750 & 2000 & - & 1900 & 2700 & 1500 & 3000 & - & \\
\hline Number & 48 & 49 & 43 & 50 & 190 & 35 & 31 & 31 & 47 & 144 & 334 \\
\hline Mean $(f)$ & 22333.4 & 26055.61 & 13631.32 & 10456.22 & - & 7772.55 & 7642.4 & 8385.83 & 5823.98 & - & \\
\hline Median ( $($ ) & 5500 & 9978 & 4000 & 3500 & - & 3800 & 3570 & 2500 & 2900 & - & \\
\hline \multicolumn{12}{|l|}{ Emp. Bonus } \\
\hline Number & 253 & - & - & - & 253 & 201 & - & - & - & 201 & 454 \\
\hline Mean $(f)$ & 5256.18 & - & - & - & - & 856.73 & - & - & - & - & \\
\hline Median ( $(\varepsilon)$ & 605 & - & - & - & - & 342 & - & - & - & - & \\
\hline \multicolumn{12}{|l|}{ Inheritance } \\
\hline Number & 50 & 51 & 71 & 64 & 236 & 92 & 84 & 111 & 77 & 364 & 600 \\
\hline Mean $(f)$ & 15800.7 & 15592.13 & 15142.03 & 19440.09 & - & 14393.12 & 13147.26 & 15718.36 & 11083.53 & - & \\
\hline Median ( $f)$ & 4025 & 4610 & 4000 & 4000 & - & 2200 & 5000 & 5000 & 2000 & - & \\
\hline \multicolumn{12}{|l|}{ Lottery } \\
\hline Number & 708 & 537 & 614 & 476 & 2335 & 802 & 500 & 616 & 405 & 2323 & 4658 \\
\hline Mean $(f)$ & 1115.85 & 1756.8 & 150.68 & 127.59 & - & 266.37 & 713.74 & 98.00 & 108.20 & - & \\
\hline \multicolumn{12}{|l|}{ Other windfall } \\
\hline Number & 56 & - & 114 & 95 & 265 & 59 & - & 107 & 103 & 269 & 534 \\
\hline Mean $(f)$ & 9613.37 & - & 6290.81 & 7437.83 & - & 6767.32 & - & 7324.23 & 6580.14 & - & \\
\hline $\begin{array}{l}\text { Median (f) } \\
\text { Building society }\end{array}$ & 1650 & - & 2100 & 764 & - & 1000 & - & 2000 & 800 & - & \\
\hline Number & - & 681 & - & - & 681 & - & 696 & - & - & 696 & 1377 \\
\hline Mean (f) & - & 3867.47 & - & - & - & - & 2891.96 & & & - & \\
\hline Median ( $f$ ) & - & 1600 & - & - & - & - & 1500 & & & - & \\
\hline Total & & & & & & & & & & & \\
\hline Number & 1237 & 1443 & 981 & 825 & 4486 & 1329 & 1443 & 982 & 762 & 4516 & 9002 \\
\hline
\end{tabular}


TABLE IV

Transitions into Self-Employment by Employment Status and Gender

\begin{tabular}{|c|c|c|c|c|c|c|c|c|c|c|c|c|c|c|c|}
\hline & \multicolumn{3}{|c|}{$\begin{array}{l}\text { 1994-1996 } \\
\text { Windf all (1995) }\end{array}$} & \multicolumn{3}{|c|}{$\begin{array}{l}\text { 1996-1998 } \\
\text { Windfall (1997) }\end{array}$} & \multicolumn{3}{|c|}{$\begin{array}{l}\text { 1997-1998 } \\
\text { Windfall (1998) }\end{array}$} & \multicolumn{3}{|c|}{$\begin{array}{l}\text { 1998-2000 } \\
\text { Windfall (1999) }\end{array}$} & \multicolumn{3}{|c|}{$\begin{array}{l}\text { Aggregate Figures } \\
\text { Windfall (1995-1999) }\end{array}$} \\
\hline & Yes & No & Total & Yes & No & Total & Yes & No & Total & Yes & No & Total & Yes & No & Total \\
\hline \multicolumn{16}{|l|}{ Transition from } \\
\hline Employment & 47 & 64 & 111 & 58 & 57 & 115 & 42 & 76 & 118 & 41 & 96 & 137 & 188 & 293 & 481 \\
\hline Of which: males & 28 & 36 & 64 & 32 & 27 & 59 & 26 & 38 & 64 & 27 & 54 & 81 & 113 & 155 & 268 \\
\hline Females & 19 & 28 & 47 & 26 & 30 & 56 & 16 & 38 & 54 & 14 & 42 & 56 & 75 & 138 & 213 \\
\hline Unemployment & 3 & 24 & 27 & 2 & 11 & 13 & 3 & 11 & 14 & 0 & 11 & 11 & 8 & 57 & 65 \\
\hline Of which: males & 2 & 18 & 20 & 2 & 8 & 10 & 3 & 9 & 12 & 0 & 9 & 9 & 7 & 44 & 51 \\
\hline Females & 1 & 6 & 7 & 0 & 3 & 3 & 0 & 2 & 2 & 0 & 2 & 2 & 1 & 13 & 14 \\
\hline Out of labour force & 13 & 22 & 35 & 11 & 9 & 20 & 9 & 19 & 28 & 2 & 28 & 30 & 35 & 78 & 113 \\
\hline Of which: males & 3 & 6 & 9 & 3 & 3 & 6 & 2 & 5 & 7 & 0 & 3 & 3 & 8 & 17 & 25 \\
\hline Females & 10 & 16 & 26 & 8 & 6 & 14 & 7 & 14 & 21 & 2 & 25 & 27 & 27 & 61 & 88 \\
\hline Totals & 63 & 110 & 173 & 71 & 77 & 148 & 54 & 106 & 160 & 43 & 135 & 178 & 231 & 428 & 659 \\
\hline
\end{tabular}

Note: Transitions are measured over a 24 month period with the respondent being recorded as "not self-employed" in year $t-1$ and as self-employed in year $t+1$. Windfalls are recorded in year $t$.

\section{EMPIRICAL RESULTS}

\subsection{Transitions into self-employment}

Our empirical methodology is to estimate through probit analysis the probability of an individual entering selfemployment $(S E)$ at time $t+1$ (i.e. $S E_{t+1} 1 / 4$ 1) given that he was not self-employed at time $t+1$ (i.e. $S E_{t+1}=0$ ). Windfall receipts are recorded at time $\mathrm{t}\left(\mathrm{WF}_{\mathrm{t}}=0 / 1\right)^{11}$. Our probit estimations for male and female respondents, both collectively and separately, are set out in Tables V-IX. Consider Table V first. We estimate six specifications of our probit equation with Specification 1 focusing on the effect of receiving a windfall per se - the windfall binary term denoting a dummy variable which takes the value of one if a windfall was received by the respondent and zero otherwise - and Specifications 2-4 focusing on the amount and/or type of windfall received. If liquidity constraints are a genuine obstacle to entrepreneurship, and if windfalls are the cleanest way of ascertaining the effects of relaxing this constraint, then we would expect some interaction between the windfall and the respondent's initial wealth. To be sure, if the liquidity constraint story is correct, then an interactive "windfall*wealth" variable should have a negative sign although larger windfalls or initial wealth should encourage transitions, the effect of the windfall should be less important for relatively wealthier individuals.

We therefore included a variable in Specifications 1-4 interacting a measure of 'wealth' (vis. 'Annual Income from Dividends and Interest $>£ 2500$ ') with the windfall-binary dummy variable ${ }^{12}$. The estimates from Specification 1 imply that the receipt of a windfall per se does not exert a significant influence on the probability of transiting to self-employment. This is not surprising - as Table II indicates, the majority of windfalls are relatively small amounts of less than $£ 100$ and it is likely that only more substantial payments will release any latent entrepreneurship within our sample. Indeed, these sentiments are confirmed by Specification 2, which shows the amount of the windfall exerting a positive but decreasing influence on the probability to transit ${ }^{13}$. Our results would thus appear to reaffirm the findings of the studies listed in Table I, and support the notion that whilst initial receipts of a windfall may enable otherwise constrained individuals to transit to self-employment, especially large gains may induce an income effect that serves to reduce participation. To be sure, receipts or more than $£ 20000-£ 22000$ reduce the probability of transition, whilst those of more than $£ 90000-£ 100000$ imply a negative transition rate ${ }^{14}$. Notice also in Specification 2 that the greater the individual's wealth, the smaller is the incremental effect of an inheritance. The interaction terms suggest that "wealthy" and "nonwealthy" respondents react quite differently to the receipt of a windfall. Recipients with unearned income in excess of $£ 2500$ are significantly less likely to transit to self-employment ceteris paribus. Holtz-Eakin et al. (1994a) report very similar results. 
Specification 3 highlights the importance of the type of windfall payment received on the probability of transmission. Redundancy payments and, to a lesser extent, inheritances are positively associated with selfemployment transition. Contrary to Lindh and Ohlsson's (1996) findings for Sweden, however, UK lottery winnings may actually reduce the probability of becoming self-employed.

The qualitative effects of a lottery win are robust to the inclusion of controls for the size of the windfall (Specification 4). The size and significance of the coefficient on redundancy pay alludes to the presence of unemployment-push inspired entrepreneurship. Such sentiments are confirmed by the finding that unemployed, but not employed, respondents are significantly more likely than the economically inactive to transit into self-employment ceteris paribus ${ }^{15}$.

There are a number of other interesting results evident from Table V. Wealthier respondents are more likely to transit to self-employment ceteris paribus ${ }^{16}$. Married and male respondents, and those whose father was self-employed when they were aged 14, are also more likely to transit. This latter finding accords with Dunn and Holtz-Eakin (2000), who also find the father to be the parental figure that unleashes intergenerational links in self-employment. The significance of the "Father Self-Employed" variable may reflect the possibility that respondents are inheriting the physical and/or human capital requisite for self-employment and supports the notion of knowledge spillovers and role models (see Schmitz,1989; Lentz and Laband, 1990).

Echoing similar findings by Holtz-Eakin et al. (1994a), Lindh and Ohlsson (1996) and Johansson (2000), we find no evidence of any household income effects in our data. There is, however, a clear non-linear age effect with the probability of transition increasing up to 48 years on average. This is consistent with the findings of a number of other studies ${ }^{17}$. Having a health condition that limits the ability of the respondent to work considerably reduces the probability of entering self-employment.

Formal education plays little role in the probability of entrepreneurship ${ }^{18}$. This may reflect the fact that higher qualified individuals are able to find more acceptable levels of personal autonomy and responsibility within professional salaried employment whilst those intent on working for themselves have no need to acquire formal qualifications. Cowling and Mitchell (1997) report similar results whilst Brown and Sessions (1998) point out in a signalling context that self-employed workers have no need to invest in formal education because they have no need to signal their productivity. This argument is especially pertinent if the decision to become self-employed is made prior to the procurement of educational attainment. Moreover, education may increase wage income more than self-employed income such that an increase in education reduces the relative reward to self-employment (see Burke et al. 2000). On the other hand, labour market characteristics such as managerial or self-employment experience may indicate an accumulation of business skill that provides an important mechanism to cushion the effect of uncertainty and thereby increases the expected return to self-employment (Pfann, 2001).

Table $\mathrm{V}$ also records the effects of regional variations in socio-economic conditions on the probability of transition through seven regional dummy variables. These show that the probability of transition is significantly higher in Scotland and the South-East than in the (default) North-West ${ }^{19}$ Georgellis and Wall (2000) claim that their analysis of British data suggests regional variations in entrepreneurial acumen, education, age, and other individual characteristics that may not be observable or measurable. For example, it has been argued that people in the North-West consume more alcohol and cigarettes than the English average (Hughes et al., 2001; Lyons and Waller, 2002). If entrepreneurship and health are correlated, as our results seem to suggest, then this could spill over into regional discrepancies in self-employment transitions.

Specifications 5 and 6 of Table $V$ exploit the relative richness of our data to further test the robustness of our findings. Failure to account for any unobserved heterogeneity in our data would bias our estimated transition probabilities. Accordingly, in Specification 5 we endeavour to control for this eventuality through a random effects specification. Our estimated q value here (i.e. the proportion of the total variance contributed by the panel-level variance component) is 0.61 and is significant at conventional levels of significance. However, although this suggests that unobserved heterogeneity is important, it is apparent that our main conclusions regarding the key variables of interest remain essentially intact.

It could be argued that 24 months is an insufficient time-frame in which to explore the full effects of a windfall, and so in Specification 6 we extended the time horizon for responding to a windfall from $t+1$ to $t+2$. To be sure, we observe the respondent's labour market status and other characteristics at time $t-1$, whether any windfall payment is received at time $t$, and finally whether any transition occurs by time $t+2$. For brevity we report in Specification 6 only the "full" model vis. the one set out in Specification 4 for the 24 month time frame. It is apparent from this (and from other non-reported specifications) that our substantive results remain the same. 
TABLE V

Tranciton pohbiliter all rempondent

\begin{tabular}{|c|c|c|c|c|c|c|c|c|c|c|c|c|}
\hline & \multicolumn{2}{|c|}{$\begin{array}{l}\text { Spel } \\
\text { Pooled Probit }\end{array}$} & \multicolumn{2}{|c|}{$\begin{array}{l}\text { Spe } 1 \\
\text { Poold Prohit }\end{array}$} & \multicolumn{2}{|c|}{$\begin{array}{l}\text { Spo } 3 \\
\text { Pooled Prabit }\end{array}$} & \multicolumn{2}{|c|}{$\begin{array}{l}\text { Spa } 4 \\
\text { Proled Probit }\end{array}$} & \multicolumn{2}{|c|}{$\begin{array}{l}\text { Spe } 3 \\
\text { Randan Effats }\end{array}$} & \multicolumn{2}{|c|}{$\begin{array}{l}\text { Sha } 6 \\
\text { Poilat Prohit }\end{array}$} \\
\hline & Gad. & Tratit. & Cof. & Tisht & Cad. & Trat. & Cot. & T-ant & Cod. & Tratat. & Gel. & Tstat. \\
\hline Wondill binary & $-0 . \omega$ & -16.61 & $=$ & $=$ & $=$ & = & w. & $=$ & $=$ & m & $=$ & $=$ \\
\hline Win ifll pyment/10 & $=$ & $=$ & 0.20 & 20 & - & - & 0.318 & 13 & ail & 09 & 0.194 & 1.81 \\
\hline Windial pyment oy/lot+al & $=$ & - & $-0.4 \|$ & -200 & - & $=$ & -0.59 & -1.9 & -0.614 & -0.8 & -0.301 & -1.74 \\
\hline \multicolumn{13}{|l|}{ Windill tyx } \\
\hline Pewnal aritent daim & $=$ & - & - & - & 0.106 & 069 & $0(0)$ & 0.5 & 0.15 & 06 & 003 & 0.0 \\
\hline Redundexy & - & $=$ & $=$ & $=$ & 0.40 & 35 & 0.38 & 30 & 0.55 & 3.14 & $0.19 !$ & 1.9 \\
\hline Interituxe & $=$ & $=$ & $=$ & $=$ & $0.1 \mathrm{~s}$ & Ist & 0,06 & 1.7 & $0.1 \%$ & $1 \mathrm{~d}$ & 004 & 1.69 \\
\hline Lattery & - & - & - & - & $-0, \hat{M}$ & -1.6 & -001 & -1.5 & -0.110 & -15 & -00074 & -1.79 \\
\hline Other windfall & - & - & - & $=$ & -0.14 & -076 & -0.115 & $-0,48$ & -026 & -1.24 & -1.194 & -1.26 \\
\hline \multicolumn{13}{|l|}{ Persmal donderitio } \\
\hline Emphyet & $-0 \omega 0$ & -0.57 & -000 & -1055 & -0.06 & -0.68 & -0.16 & -061 & -0.05 & -061 & -0.017 & -0.27 \\
\hline Unemployd & 0213 & $10 !$ & 029 & 10 & $0 x$ & 244 & $02 y$ & 24 & $0 \mathrm{H}$ & $2 y$ & 0.29 & 20 \\
\hline Mak & 0.044 & 25 & 0101 & 25 & $0.0,4$ & 25 & 0.94 & 24 & 0.142 & 20 & 0.32 & 260 \\
\hline $\mathrm{Ag}$ & 1.161 & 28 & 1.145 & 242 & 1.12 & 241 & 1.10 & 24 & 1.310 & 264 & $10 \%$ & 1.4 \\
\hline Ays $8 / 00$ & -120 & $-2 n$ & $-\| M$ & $-2 n$ & -1.15 & -281 & $-1.14]$ & -284 & -0.92 & -2.44 & -1055 & -22 \\
\hline Marrid & 0.015 & 025 & 00012 & 02 & 0.012 & 02 & 0013 & 03 & 044 & 061 & -005 & -0.51 \\
\hline Nor af chldten & $0 \omega$ & all & 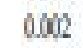 & ail2 & 0.00 & 000 & 0,01 & ăt & 0004 & 0.12 & 0016 & 069 \\
\hline Non ahite & 0.055 & 06 & 000 & 0.14 & 0.15 & 0.60 & 0052 & 061 & $0 \omega M$ & 0.9 & 0065 & 0.69 \\
\hline Houshald incme/ino & -0.018 & -1.31 & -0017 & -130 & -006 & $-1 M$ & -0.017 & -140 & $-0 \omega 2$ & -1.04 & -0.04 & -1.69 \\
\hline Health limit avor & -0.267 & -47 & $-0.26 t$ & $-4 \%$ & $-02 S$ & -37 & -0.29 & -47 & -0.87 & -43 & -0110 & -2.17 \\
\hline \multicolumn{13}{|l|}{ Anmul incone from dv. $k$ int. } \\
\hline$<$ flim & $-0 \mathrm{~m}$ & -06 & $-0,01$ & -0.81 & $-0, \pi$ & -0.7 & $-0 . \pi$ & $-1,73$ & -0044 & $-0 \mathrm{k}$ & 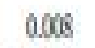 & 0.19 \\
\hline flö 250 & 0.0 .14 & all & aOAD & 0.15 & 0.019 & 0.14 & 0014 & a.lo & aom & 076 & -0.016 & -1.12 \\
\hline $\operatorname{sen}$ & 0.20 & $\mid 81$ & a. 10 & 186 & 0.19 & 1.96 & $0.1 \%$ & 19 & 021 & 1.9 & 0.145 & 1.9 \\
\hline s.to6 $x$ Winffall pryments & $=$ & $=$ & -0.197 & 189 & -0.12 & 1.91 & -0.14 & $\mathbb{1 . 9 4}$ & -0651 & -1.9 & -010 & -201 \\
\hline \multicolumn{13}{|l|}{ Edration } \\
\hline Degrex & 0.011 & $a s$ & $0 \omega t$ & all6 & 0.010 & $a 2$ & $06 \%$ & 0.21 & ans & 0.51 & $0 \omega$ & 0.6 \\
\hline A kue & 0.121 & 1.21 & 0.12 & 12 & 0.12 & 1.4 & 0.12 & 125 & $0 \omega$ & 06 & $-0 \omega 1$ & -0.54 \\
\hline $0 \mathrm{kwd}$ & -0.45 & $-(14)$ & $-0,04$ & -104 & -0.049 & -0.51 & -0.00 & -0.12 & -0.116 & $-0 \mathrm{n}$ & -0.014 & -1.2 \\
\hline Other qualfiation & -0.42 & -106 & -0045 & -018 & -0.042 & -116 & $-0,43$ & -013 & -0.013 & -000 & 003 & 0.39 \\
\hline \multicolumn{13}{|l|}{ Intergenerional links } \\
\hline Father alfemployd & 0.24 & 475 & 0.27 & 4.81 & 0.24 & 4.50 & $\Delta W$ & $4 x$ & 0.48 & $4 \%$ & $0 w$ & 4.6 \\
\hline Mother stifemployd & 0.043 & 0.50 & 0044 & 05 & 0.04 & 0.55 & 0.047 & 0.5 & $\operatorname{ang}$ & 0.4 & 0.657 & 0.9 \\
\hline \multicolumn{13}{|l|}{ Labor market } \\
\hline Manzgrial apprime & 0.012 & $1 \mathrm{~s}$ & 064 & 1.74 & 0.64 & 1.73 & $0 M$ & 16 & 0318 & 26 & 0.199 & $2 \%$ \\
\hline 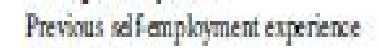 & 0.467 & 990 & 046 & $9 \mathrm{~s}$ & 0.47 & 995 & 0.41 & 9.95 & -0222 & $-\mid \not i 0$ & 040 & 8.98 \\
\hline Dunation ${ }^{3}$ & $-00 \mathrm{~s}$ & -23 & -000 & $-2 x$ & $-0.0 s$ & -24 & $-0, \omega$ & $-2 x$ & -005 & -28 & -0.05 & -22 \\
\hline Lad UN Rato' & 0.01 & 164 & $0 \omega \mathbf{2}$ & 043 & 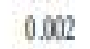 & 0.34 & $0 \omega$ & 0.57 & $\underline{0 \omega}$ & all & 0,013 & 0.5 \\
\hline
\end{tabular}


TABLE V. Gontinued

\begin{tabular}{|c|c|c|c|c|c|c|c|c|c|c|c|c|}
\hline & \multicolumn{2}{|c|}{$\begin{array}{l}\text { Spe l } \\
\text { Poold Frobit }\end{array}$} & \multicolumn{2}{|c|}{$\begin{array}{l}\text { Spe } 2 \\
\text { Pooled Probt }\end{array}$} & \multicolumn{2}{|c|}{$\begin{array}{l}\text { Spes } 3 \\
\text { Pooled Probit }\end{array}$} & \multicolumn{2}{|c|}{$\begin{array}{l}\text { Spe } 4 \\
\text { Pooted Probit }\end{array}$} & \multicolumn{2}{|c|}{$\begin{array}{l}\text { Spes } \\
\text { Rendom Efeds }\end{array}$} & \multicolumn{2}{|c|}{$\begin{array}{l}\text { Spa } 6 \\
\text { Polad Probit }\end{array}$} \\
\hline & Gef. & T-hat. & Cod. & Tustat. & Cod. & That & Caf. & TStat & Caef. & Tstat. & Cat. & Tstat. \\
\hline \multicolumn{13}{|l|}{ Region } \\
\hline South East & aldo & $2 x$ & 0.16 & 231 & 0.167 & $2 y$ & a. 6 & 2.5 & 027 & 1.19 & $a 2 z$ & 327 \\
\hline South Wert & $\omega 0 /$ & 000 & 0.01 & 001 & -0001 & -001 & -0.01 & -001 & -0.05 & -003 & -0.00 & $-0 \%$ \\
\hline East Angh & 0160 & 1.55 & 0.160 & 1.55 & 0.16 & 1.5 & 0.16 & 1.5 & 0.15 & 1.69 & $0.1 \%$ & 1.43 \\
\hline Mallund & 006 & 03 & 0.00 & 085 & 006 & 0.8 & 0062 & 0.57 & $0 M$ & 088 & 0.125 & $L h$ \\
\hline Yorkhise & 0015 & 0.21 & 0.018 & 0.23 & 0.013 & 0.17 & 0014 & 0.18 & 0.17 & 0.12 & $0.2 s$ & 1.52 \\
\hline Wals & 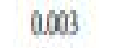 & 000 & 0.04 & 0.4 & 006 & 0.05 & 0000 & 006 & 0,06 & 003 & -0.061 & 048 \\
\hline Sotant & 0.14 & 1.76 & 0.147 & $\mid \mathbf{A I}$ & 0152 & 13 & 0.154 & 1.89 & 0.21 & 1,45 & 0.19 & 26 \\
\hline \multicolumn{13}{|l|}{ Year dunmien } \\
\hline 194 & $-0 \omega s$ & $-|3|$ & -0104 & -13 & $-0 . \omega$ & $-1,4$ & $-10 \%$ & $-\mid .51$ & -0.044 & -0.47 & -0.04 & -136 \\
\hline 191 & -0.04 & -0.54 & -000 & -0.60 & -0.05 & -0.59 & -0.69 & -0.9 & -1000 & -0.21 & $0 \omega$ & $0 \hat{0}$ \\
\hline 198 & -00 & -001 & 0.06 & 006 & $-0 \overline{0}$ & -0.10 & -0.010 & -0.10 & 0.116 & 080 & $=$ & $=$ \\
\hline Constant & -250 & -437 & -240 & $-9,93$ & $-24 s$ & $-9 B$ & -2.46 & $-4 x$ & $=$ & $=$ & -204 & -892 \\
\hline Nurher of akenation & 21813 & & 21813 & & 21813 & & 21813 & & 21813 & & 1526 & \\
\hline Max. traniton andiflf & - & & now & & $=$ & & $\operatorname{mot}$ & & $m \omega$ & & E1800 & \\
\hline Zero trancition ainde ${ }^{d}$ & = & & $\$ 950$ & & ச1క40ல் & & Exw0 & & Elowion & & flogo & \\
\hline Wald $y^{2}(d)$ & $356 \omega_{0}$ & & $W_{0}$ & & $35 \% .00 l_{(4 !)}$ & & $3 \mathrm{H}_{40}$ & & $206 \mathbb{R}_{4 i}$ & & $361_{i 0}$ & \\
\hline Log tikelihod & -2733 & & -2715 & & -2749 & & -274 & & -2646 & & -21458 & \\
\hline
\end{tabular}

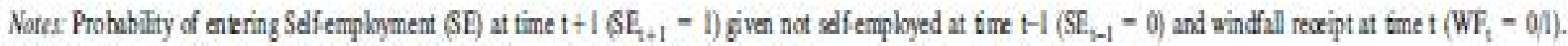

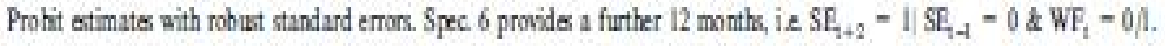

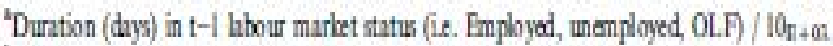

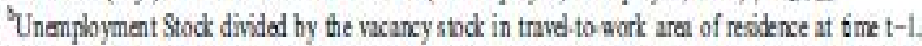

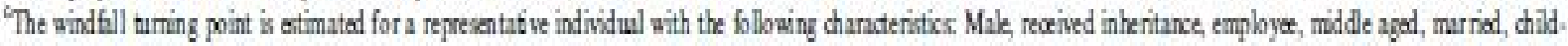

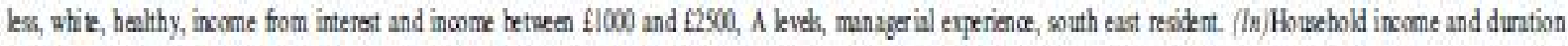

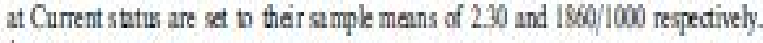

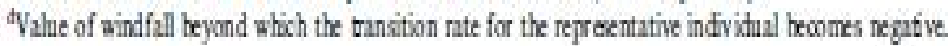


TABLE VI

Subsample tunsition prohabilities

\begin{tabular}{|c|c|c|c|c|c|c|c|c|c|c|c|c|}
\hline & \multicolumn{2}{|c|}{ Spec 2M, males } & \multicolumn{2}{|c|}{ Spec. 3M, males } & \multicolumn{2}{|c|}{ Spec. 4M, males } & \multicolumn{2}{|c|}{ Spec. 2F, females } & \multicolumn{2}{|c|}{ Spec. 3F, females } & \multicolumn{2}{|c|}{ Spec, 4F, females } \\
\hline & Coef. & T-stat. & Coef. & Tstat & Coef. & Tstat & Cod. & Totat. & Coef. & Tistat & Cod. & T wat. \\
\hline Windfall pyyment/10 $\mathrm{n}+0 \mathrm{~s}$ & 0.153 & 200 & - & - & 0.141 & 1.98 & 0.102 & 1.83 & - & - & 0.0087 & 1.71 \\
\hline Windfall pyyment $s q / 10_{n+a n}$ & -0.186 & -2.17 & - & - & -0.113 & -1.85 & -0.141 & -1.73 & $=$ & - & -0.100 & -1.72 \\
\hline \multicolumn{13}{|l|}{ Windfall type } \\
\hline Personal accident duim & = & - & $0.0 \times 3$ & 0.40 & 0.048 & 0.22 & $=$ & $=$ & 0.180 & 0.68 & 0.157 & 0.59 \\
\hline Redundancy & - & $=$ & 0.424 & 3.01 & 0.362 & 2.34 & $=$ & - & 0.375 & 209 & 0.338 & 1.96 \\
\hline Inheritance & - & - & 0.138 & 1.99 & 0.104 & 188 & - & - & 0.134 & 1.85 & 0.124 & 1.77 \\
\hline Lottery & " & $=$ & -0.118 & -1.91 & -0.119 & -1.92 & $=$ & $=$ & -0.022 & -0.34 & -0.022 & -0.33 \\
\hline Other windfall & - & - & -0.024 & -0.15 & -0.065 & -0.42 & = & $=$ & -0.148 & -0.79 & -0.168 & -0.87 \\
\hline Houschold income/ 10000 & -0.032 & -200 & -0.030 & -1.97 & -0.031 & -1.99 & -0.006 & -0.38 & -0.006 & -0.39 & $-0.00 \%$ & -0.40 \\
\hline \multicolumn{13}{|l|}{ Annul income from dv. and int } \\
\hline$<f 100$ & 0.009 & 0.16 & 0.016 & 0.29 & 0.014 & 0.26 & -0.074 & -1.39 & -0.072 & -134 & -0.072 & -1.35 \\
\hline flo00- 12500 & 0.010 & 0.06 & 0.042 & 0.25 & 0.032 & 0.19 & -0.008 & -0.04 & -0.005 & -0.03 & -0.006 & -0.03 \\
\hline$>\$ 2500$ & 0.136 & 1.83 & 0.182 & 1.94 & 0.155 & 1.95 & 0.245 & 1.86 & 0.241 & 1.83 & 0.243 & 184 \\
\hline SE250 x mindfall puments & -0.127 & -2.04 & -0.112 & -1.98 & -0.107 & -203 & -0.194 & -1.91 & -0.153 & -1.59 & -0.168 & -1.94 \\
\hline \multicolumn{13}{|l|}{ Eduration } \\
\hline Degreet & -0.067 & -1.14 & -0.068 & -1.15 & -0.068 & -1.16 & 0.009 & 1.98 & 0.095 & 200 & 0.095 & 2.03 \\
\hline$A$ bevel & 0.074 & 1.83 & 0.069 & 1.91 & 0.000 & 1.95 & 0.191 & 1.82 & 0.202 & 184 & 0.204 & $|8|$ \\
\hline 0 kevel & -0.065 & -0.46 & -0.090 & -0.49 & -0.010 & -0.49 & -0.024 & -0.18 & -0.020 & -0.15 & -0.021 & -0.16 \\
\hline Other qualifications & -0.101 & -0.55 & -0.104 & -0.56 & -0.104 & -0.56 & -0.007 & -0.05 & 0.001 & 0.01 & 0,000 & 0.00 \\
\hline \multicolumn{13}{|l|}{ Intergenentional links } \\
\hline Futher selfemployod & 0.272 & 4.00 & 0.269 & 3.95 & 0.271 & 3.98 & 0.189 & 2.79 & 0.191 & 283 & 0.192 & 283 \\
\hline Mother selfiemployed & -0.064 & -0.47 & -0.059 & -0.42 & -0.057 & -0.42 & 0.139 & 1.24 & 0.141 & 1.26 & 0.141 & 1.26 \\
\hline \multicolumn{13}{|l|}{ Labor market } \\
\hline Employed & 0.115 & 1.11 & 0.108 & 1.04 & 0.110 & 1.06 & -0.065 & -1.73 & -0.072 & -188 & -0.072 & -1.71 \\
\hline Unemployed & 0.420 & 3.53 & 0.405 & 3.40 & 0.400 & 3.43 & 0.056 & 1.83 & 0.047 & 1.74 & 0.047 & 1.73 \\
\hline Manag erial experience & 0.194 & 1.91 & 0.183 & $1 / 88$ & 0.182 & 1.85 & 0.000 & 1.05 & 0.002 & 1.09 & 0.079 & 1.02 \\
\hline Previsus self employment Experience & 0.467 & 7.40 & 0.458 & 7.41 & 0.468 & 7.40 & 0.471 & 6.34 & 0.47 & 6.41 & 0.476 & 6.40 \\
\hline Dunation & -0.212 & -1.52 & -0.207 & -1.49 & -0.214 & -1.54 & -0.298 & -2.06 & -0.297 & -2.06 & -0.299 & -2.06 \\
\hline Number of olservations & 9997 & & 9597 & & 9997 & & 12216 & & 12216 & & 12216 & \\
\hline Wald $\chi^{2}\left({ }_{4}\right)$ & $153.50_{(\mathrm{CS})}$ & & $160.25_{(\mathrm{cas})}$ & & $164.77_{(4)}$ & & $140.11_{05}$ & & $148.17 \mathrm{con}$ & & $149.95_{(4)}$ & \\
\hline Loglikelihond & -1413.6 & & -1410.1 & & -14088 & & -13978 & & -1395.3 & & -13950 & \\
\hline
\end{tabular}

Noter:

(1) The ahove modds alo contin the other contol variables Isted in Table V.

(2) Duration (day) in $\mathrm{t}-1$ labour market status (ie. anployed, unamployed, OL.F)/10 10 +an

Probit Estimates with robust standend errors 
TABLE VII

Subsample transition prohabilities with gender intenctions

\begin{tabular}{|c|c|c|c|c|c|}
\hline Females & Cod. & T-stat. & Males & Coef. & $x^{2}(1)$ \\
\hline \multicolumn{6}{|l|}{ Spec I INTIR.ACTnow } \\
\hline Windfall binary & -0.050 & -1.03 & $\begin{array}{l}\text { (Windfall-hinary })+(\text { Windfall hinary } \times \text { male }) \\
\text { Log - Fielihood: }-2830.82\end{array}$ & 0.061 & 1.04 \\
\hline \multicolumn{6}{|l|}{ Spec. 2 PTTRRACTON } \\
\hline Wintfall payment/ $10_{n+0 s}$ & 0.112 & 1.73 & (Windfall payment $\left./ 10_{T+0}\right)+\left(\right.$ Windfill payment $/ 10_{n+m} \times$ male) & 0.211 & 6.08 \\
\hline Wintfall payment $s q, 10 \mathrm{n}+\mathrm{c}$ & -0.137 & -1.63 & (Windfall payment $\left.s q / 10_{\mathrm{T}+\mathrm{m}}\right)+\left(\right.$ Windfall payment $\left.s q . / 10_{\mathrm{n}+\mathrm{n}} \times \mathrm{male}\right)$ & -0.309 & -4.55 \\
\hline$>£ 2500 \times$ windfall payment & -0.118 & -188 & $\begin{array}{l}\text { (>£2500x Windfill Payment })+(>£ 2500 \times \text { Windfill Payment } x \text { mak }) \\
\text { Log - Ekelihood: }-2827 . ?\end{array}$ & -0.171 & -4.58 \\
\hline \multicolumn{6}{|l|}{ 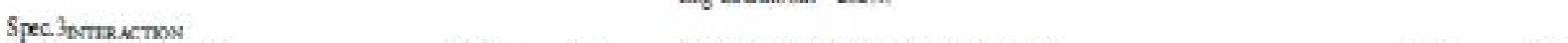 } \\
\hline Personal acoident chim & 0.119 & 0.68 & (Acaident duim) $+($ Aocident chim $\times$ male $)$ & 0.115 & 0.32 \\
\hline Redundancy & 0.308 & 207 & (Redundancy) + (Rodundancy $\times$ make) & 0.473 & 11.48 \\
\hline Inheritance & 0.165 & 185 & (Inheritance) $+($ Inheritance $\times$ male) & 0.350 & 9.01 \\
\hline Lottery & -0.069 & -0.34 & (Lottery) + (Lotter $y \times$ male $)$ & -0.064 & -1.20 \\
\hline Other windfall & -0.189 & -0.79 & (Other windfall) $+($ Other windfall $x$ male) & -0.005 & 0.01 \\
\hline$>f 2500 x$ windfall payment & -0.107 & -1.83 & $\begin{array}{l}\text { (> } 2500 x \text { windfall payment })+(>£ 2500 \times \text { windfall payment } x \text { make) } \\
\text { Log. Fkel ihood: }-2827.7\end{array}$ & -0.148 & -4.47 \\
\hline \multicolumn{6}{|l|}{ 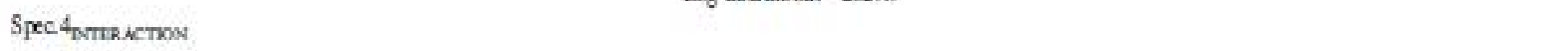 } \\
\hline Wintfall payment/10 $\mathrm{r}+0 \mathrm{~s}$ & 0.005 & $|.6|$ & (Windfall payment $\left./ 10_{n+03}\right)+\left(\right.$ Wind fll payment $/ 10_{n+0} \times$ male $)$ & -0.063 & -1.92 \\
\hline Windfall payment sq, $10_{n+0}$ & -0.000 & -1.62 & (Windfall payment sq. $\left./ 10_{\mathrm{n}+\mathrm{e}}\right)+\left(\right.$ Windfall payment $s q .10_{\mathrm{n}+0} \times$ male) & -0.204 & -1.83 \\
\hline Windfall Type: personal acrident claim & 0.005 & 0.59 & (Acaident duim) $+($ Accident claim $\times$ mak $)$ & 0.018 & 0.16 \\
\hline Redundency & 0.113 & 1.96 & (Redundancy) + (Redundancy $\times$ male) & 0.214 & 6.93 \\
\hline Inheritance & 0.105 & 1.97 & (Inheritance) + (Inheritance $x$ malk) & 0.263 & 7.02 \\
\hline Lottery & 0.289 & -0.33 & (Lottery) + (Lottery $x$ mak $)$ & 0.292 & 1.26 \\
\hline Other windfall & -0.190 & -0.87 & (Other windfall $)+($ Other windfall $x$ male) & -0.029 & -0.09 \\
\hline$>f 2500 x$ windfall payment & -0.095 & $-|8|$ & $\begin{array}{l}\text { (> f2500 } x \text { mindfall payment })+(>£ 2500 \times \text { windfall payment } x \text { make) } \\
\text { Log Flikelihood: }-2820.7\end{array}$ & -0.139 & -4.09 \\
\hline
\end{tabular}

Novx: "All four specifications are estimated on a sta bod sample of 9597 males and 12216 females (botal sample 21813 ), and all contain the other control variahles listod in Tahle V. 
TABLE VIII

Subsample tranation proba hilites - prohit etimater with rohust standard errors ${ }^{2}$

\begin{tabular}{|c|c|c|c|c|c|c|c|c|c|c|c|c|}
\hline & \multicolumn{2}{|c|}{ Spec. 2E employed } & \multicolumn{2}{|c|}{ Spec 2U unemployed } & \multicolumn{2}{|c|}{ Spec 2OLF oif } & \multicolumn{2}{|c|}{ Spec 4E employed } & \multicolumn{2}{|c|}{ Spec. $A U$ unemployed } & \multicolumn{2}{|c|}{ Spect4OLF olf } \\
\hline & Coef. & T:stat. & Coef. & $T_{\text {etat. }}$ & Coef. & T-stat & Cod. & Tistat & Coef. & T wath. & Coef. & T rat. \\
\hline Windfall payment/10 $10_{n+0}$ & 0.189 & 2.43 & -0.346 & -1.72 & 0.102 & 205 & 0.302 & 1.94 & 0.241 & 1.73 & 0.127 & 1.99 \\
\hline Windfall payment sq/ $/ 10_{n+a t}$ & -0.269 & -2.29 & -0.999 & -1.67 & -0.167 & -1.77 & -0.414 & -1.75 & -0.849 & -1.61 & -0.267 & -1.74 \\
\hline \multicolumn{13}{|l|}{ Windfall type } \\
\hline Personal accident daim & - & - & - & - & - & - & 0.225 & 1.43 & - & - & - & - \\
\hline Redundancy & - & $=$ & $=$ & $=$ & $=$ & - & 0.385 & 3.14 & - & $=$ & - & - \\
\hline Inheritance & - & $=$ & = & $=$ & = & $=$ & 0.202 & 1.67 & $=$ & - & 0.215 & 1.62 \\
\hline Lotery & $=$ & - & $=$ & $=$ & - & - & -0.069 & -1.74 & -0.595 & -2.70 & -0.062 & -1.88 \\
\hline Other windell & - & $=$ & $=$ & - & - & * & -0.082 & -0.64 & $=$ & - & -0.149 & -0.49 \\
\hline \multicolumn{13}{|l|}{ Persmal chancteritis } \\
\hline Household income/10000 & -0.108 & -2.37 & 0.042 & 0.85 & 0.167 & 1.02 & -0.113 & -2.36 & 0.037 & 0.73 & 0.025 & 1.03 \\
\hline Male & 0.091 & 2.17 & 0.329 & 2.24 & 0.052 & 0.48 & 0.091 & 2.16 & 0.335 & 2.29 & 0.049 & 0.46 \\
\hline $\mathrm{Agge}_{\mathrm{g}}$ & 1.975 & 1.28 & 1.118 & 2.20 & 0.925 & $2.2 !$ & 2.058 & 1.33 & 1.207 & 2.41 & 1.010 & 221 \\
\hline Agge sq/ $/ 100$ & -0.0029 & -1.47 & -0.998 & -2.12 & -0.906 & -2.61 & -0.030 & -1.53 & -1.094 & -2.29 & -0.870 & -2.64 \\
\hline Heal th limits work & -0.151 & -1.88 & -0.203 & -0.96 & -0.370 & -3.02 & -0.158 & -1.96 & -0.183 & -0.86 & -0.368 & -3.00 \\
\hline \multicolumn{13}{|l|}{$\begin{array}{l}\text { Anmual income from dvidends } \\
\text { and interest }\end{array}$} \\
\hline$<f 1000$ & -0.062 & $-\mid A 2$ & 0.159 & 1.03 & -0.039 & -0.40 & -0.058 & -133 & 0.172 & 1.10 & -0.039 & -0.43 \\
\hline$f 1000-22500$ & 0.003 & 0.02 & 0.422 & 1.72 & -0.290 & -0.72 & 0.018 & 0.13 & 0.412 & 1.67 & -0.299 & -0.74 \\
\hline$>\$ 2500$ & 0.204 & 1.93 & 0.026 & 0.04 & 0.029 & 0.08 & 0.218 & 1.97 & -0.072 & -0.13 & 0.041 & 0.11 \\
\hline Sf $2500 \mathrm{x}$ windfall pryments & 0.066 & 1.91 & - & $=$ & - & $=$ & 0.081 & 1.85 & - & $=$ & $=$ & - \\
\hline \multicolumn{13}{|c|}{ Bducation } \\
\hline Degree & -0.012 & -0.25 & 0.092 & 0.63 & 0.018 & 0.16 & -0.009 & -0.18 & 0.091 & 0.61 & 0.015 & 0.13 \\
\hline A level & 0.045 & 0.37 & 0.409 & 1.09 & 0.213 & 0.99 & 0.049 & 0.40 & 0.372 & 0.98 & 0.203 & 0.95 \\
\hline 0 kvel & -0.092 & -0.83 & 0.094 & 0.23 & 0.050 & 0.22 & -0.098 & -0.87 & 0.066 & 0.15 & 0.031 & 0.14 \\
\hline Other qualfications & -0.065 & -0.48 & 0.642 & 1.64 & -0.505 & -1.29 & -0.060 & -0.44 & 0.701 & 1.74 & $-0.52 !$ & -1.33 \\
\hline \multicolumn{13}{|l|}{ Intergener at onal links } \\
\hline Father selfemployed & 0.252 & 4.69 & 0.283 & 1.83 & -0.012 & -0.10 & 0.253 & 4.71 & 0.259 & 189 & -0.016 & -0.13 \\
\hline Mother self employed & 0.054 & 0.55 & $0.2 m$ & 0.59 & -0.114 & -0.48 & 0.060 & 0.62 & 0.247 & 0.77 & -0.109 & -0.46 \\
\hline \multicolumn{13}{|l|}{ Lahor market } \\
\hline Managerial experience & 0.113 & 2.25 & -0.085 & -0.32 & 0.074 & 0.35 & 0.111 & 2.21 & -0.022 & -0.08 & 0.07 & 0.36 \\
\hline $\begin{array}{l}\text { Previcus relf-employment } \\
\text { experience }\end{array}$ & 0.423 & 7,49 & 0.550 & 3.52 & 0.630 & 5.52 & 0.425 & 7.52 & 0.565 & 3.53 & 0.643 & 5.62 \\
\hline Duration ${ }^{6}$ & -0.010 & -0.83 & -0.026 & -3.49 & -0.072 & -3.11 & -0.010 & -0.82 & -0.027 & -3.57 & -0.073 & -3.14 \\
\hline Number of ohrervations & 16109 & & 1134 & & 4570 & & 16109 & & 1134 & & 4570 & \\
\hline Wald $\chi^{2}(d)$ & $164.75(\mathrm{~m})$ & & $81.14(x)$ & & $136.24(x)$ & & $181.40 \mathrm{cos})$ & & $69.6 .1 \mathrm{x}(\mathrm{x})$ & & $141.85(39)$ & \\
\hline Log thellihood & -2093.6 & & -214.8 & & -475.7 & & -20663 & & -200.6 & & -473.6 & \\
\hline
\end{tabular}

Notes: "The ahove modek alk contin the other control variables Listed in Table V.

"Out of labour force.

'Duration (days) in $\mathrm{t}-1$ labour market status (i.e employed, unemployed, OLF)/10 $\mathrm{n}+0 \mathrm{~s}$ 
TABLE IX

Survival prohatilites: all rerpondents

\begin{tabular}{|c|c|c|c|c|c|c|c|c|c|c|c|c|}
\hline & \multicolumn{2}{|c|}{$\begin{array}{l}\text { Spec IS } \\
\text { All respondents }\end{array}$} & \multicolumn{2}{|c|}{$\begin{array}{l}\text { Spec } 2 S \\
\text { All respondents }\end{array}$} & \multicolumn{2}{|c|}{$\begin{array}{l}\text { Spa } 3 S \\
\text { All respondents }\end{array}$} & \multicolumn{2}{|c|}{$\begin{array}{l}\text { Spec 4S } \\
\text { All respondents }\end{array}$} & \multicolumn{2}{|c|}{$\begin{array}{l}\text { Spec 4MS } \\
\text { males }\end{array}$} & \multicolumn{2}{|c|}{$\begin{array}{l}\text { Spec 4RS } \\
\text { females }\end{array}$} \\
\hline & Coef. & T-stat. & Cod. & T-stat. & Coef. & T-stat & Coef. & $T$ tat. & Coef. & T-sat & Cod. & Tstat \\
\hline Windfall hinary & 0.131 & 1.56 & $=$ & $=$ & = & - & * & - & " & $=$ & * & - \\
\hline Windfall payment $10_{\mathrm{T}+a \mathrm{t}}$ & $=$ & $=$ & -0.091 & -1.91 & - & - & -0.019 & -1.66 & -0.016 & -1.06 & -0.066 & -0.25 \\
\hline Windfill pyyment sq, $/ 10_{n+\infty}$ & - & - & 0.016 & 1.09 & & & 0.015 & L.02 & 0.042 & 0.17 & 0.012 & 0.4 \\
\hline \multicolumn{13}{|l|}{ Windfill type } \\
\hline Inheritunce & - & $=$ & $=$ & - & -0.172 & -2.35 & -0.165 & -2.06 & -0.184 & -200 & -0.166 & -1.96 \\
\hline Lottery & = & $=$ & = & $=$ & 0.159 & 2008 & 0.163 & 2.14 & 0.208 & 2.28 & 0.006 & 0.04 \\
\hline Other windfall & & - & = & - & -0.246 & -1.37 & -0.191 & -1.05 & -0.006 & -0.03 & -0.664 & -1.97 \\
\hline \multicolumn{13}{|l|}{ Personal chancteris 605} \\
\hline Male & 0.373 & 539 & 0.396 & 5.71 & 0.379 & 5.45 & 0.386 & 5.54 & - & - & - & $=$ \\
\hline Age & 0.128 & 6.45 & 0.133 & 6.57 & 0.130 & 6.42 & 0.132 & 6.48 & 0.125 & 5.12 & 0.190 & 4.67 \\
\hline Age $s / 100$ & -0.150 & -6.42 & -0.156 & -6.53 & -0.153 & -6.38 & -0.154 & -6.44 & -0.145 & -5.00 & -0.224 & -4.56 \\
\hline Married & 0.041 & $0.5 !$ & 0.036 & 0.46 & 0.031 & 0.40 & 0.033 & 0.42 & 0.027 & 0.28 & 0.056 & 0.40 \\
\hline Nos. of children & -0.067 & -200 & -0.009 & -2.10 & -0.067 & -204 & -0.069 & -2.08 & -0.047 & -1.16 & -0.130 & -2.04 \\
\hline Non-white & 0.110 & 0.75 & 0.078 & 0.51 & 0.099 & 0.65 & 0.008 & 0.58 & 0.188 & 0.95 & -0.152 & -0.58 \\
\hline Household income/ 10000 & -0.015 & -1.00 & -0.012 & -0.85 & -0.0 .14 & -0.99 & 0.013 & -0.94 & -0.015 & -0.18 & -0.024 & -1.16 \\
\hline Health limits work & $0.03 !$ & 0.27 & -0.020 & -1.87 & -0.035 & -1.79 & -0.000 & -1.75 & -0.24 & -1.99 & -0.282 & -1.69 \\
\hline \multicolumn{13}{|l|}{ Annul income from div. \& int. } \\
\hline$<f l 00$ & 0.233 & 3.64 & 0.250 & 3.94 & 0.249 & 3.83 & 0.253 & 3.89 & 0.221 & 2.7 & 0.307 & 2.57 \\
\hline fiove $£ 2500$ & 0.480 & 2.16 & 0.524 & 2.42 & 0.499 & 2.32 & 0.515 & 2.38 & 0.498 & 1.94 & 0.668 & 1.49 \\
\hline$>\$ 2500$ & -0.132 & -0.75 & -0.145 & -0.81 & -0.131 & -0.73 & -0.138 & -0.76 & -0.093 & -0.46 & -0.685 & -1.29 \\
\hline SE2500 $x$ windfall pyments & -0.013 & -0.97 & -0.004 & -1.95 & -0.100 & -1.88 & -0.011 & -1.92 & 0.000 & 0.15 & $=$ & $=$ \\
\hline \multicolumn{13}{|l|}{ Eduation } \\
\hline Degree & 0.146 & 1.66 & 0.149 & 1.70 & 0.162 & 1.85 & 0.167 & 1.90 & 0.098 & 0.91 & 0.353 & 2.13 \\
\hline$A$ kevel & 0.100 & 0.83 & 0.100 & 0.82 & 0.112 & 0.91 & 0.115 & 0.94 & 0.151 & 101 & 0.160 & 0.70 \\
\hline 0 level & 0.034 & 0.32 & 0.025 & 0.23 & 0.039 & 0.36 & 0.066 & 0.34 & 0.039 & 0.31 & 0.190 & 0.64 \\
\hline Other qualifications & 0.182 & 1.51 & 0.208 & 1.7 & 0.208 & 1.78 & 0.217 & 1.86 & 0304 & 1.95 & 0.114 & 0.55 \\
\hline \multicolumn{13}{|l|}{ Intergenentional links } \\
\hline Father self-enployed & 0.145 & 1.90 & 0.146 & 1.86 & 0.143 & $|8|$ & 0.145 & 1.84 & 0.182 & 189 & 0.051 & 0.35 \\
\hline Mother relf-employed & 0.106 & 0.83 & 0.117 & 0.89 & 0.103 & 0.78 & 0.100 & 0.76 & 0.227 & 1.27 & -0.084 & -0.40 \\
\hline \multicolumn{13}{|l|}{ Labor market } \\
\hline Has employes & 0.512 & 6.99 & 0.513 & 6.81 & 0.508 & 6.75 & 0.509 & 6.75 & 0.456 & 4.94 & 0.678 & 4.90 \\
\hline Previous selfemployment ex perience & -0.034 & -1.92 & -0.039 & -1.99 & -0.032 & -1.97 & $-0,034$ & $-2.0 \mathrm{t}$ & -0.061 & -1.96 & $-0.00 s$ & -0.06 \\
\hline Professinnal & 0.571 & 2.27 & 0.585 & 2.35 & 0.572 & 230 & 0.576 & 2.31 & 0.327 & 2.01 & 1.285 & 2.38 \\
\hline Manager & 0.407 & 2.52 & 0.399 & 2.38 & 0.488 & 2.55 & 0.420 & 2.50 & 0.139 & 1.62 & 0.879 & 3.20 \\
\hline Other non -manul & 0.161 & 0.8 & 0.174 & 0.79 & 0.175 & 0.99 & 0.166 & 0.75 & 0.429 & 1.28 & -0.014 & -0.04 \\
\hline Skilled manual & 0.37 & 2.28 & 0.376 & 2.17 & 0.302 & 2.21 & 0.379 & 2,19 & 0.320 & 1.98 & 0.151 & 0.40 \\
\hline Duration & $0.06 !$ & 4.02 & 0.063 & 532 & 0.062 & 5.22 & 0.063 & 5.27 & 0.175 & 5.24 & 0.098 & 1.69 \\
\hline
\end{tabular}




\begin{tabular}{|c|c|c|c|c|c|c|c|c|c|c|c|c|}
\hline \multicolumn{13}{|c|}{ TABLE IX Continued } \\
\hline Loal U/V ratio & -0.020 & -2.08 & -0.022 & -2.39 & -0.022 & -2.41 & -0.022 & -2.40 & -0.028 & -3.06 & -0.030 & -2.15 \\
\hline \multicolumn{13}{|l|}{ Indus try } \\
\hline Agriculture & 0.265 & 2.08 & 0.245 & 1.88 & 0.258 & 1.98 & 0.258 & 1.97 & 0.146 & 1.78 & 1.261 & 3.15 \\
\hline Engineering & 0.052 & 0.38 & 0.064 & 0.46 & 0.060 & 0.43 & 0.065 & 0.46 & 0.084 & 0.55 & 0.096 & 0.22 \\
\hline Manufacturing & -0.193 & -1.66 & -0.195 & -1.59 & -0.194 & -1.57 & -0.199 & -1.61 & -0.008 & -1.57 & -0.359 & -1.47 \\
\hline Construction & 0.225 & 2.91 & 0.212 & 2.75 & 0.215 & 2.77 & 0.209 & 2.70 & 0.218 & 2.56 & - & - \\
\hline Distribution & -0.028 & -0.39 & -0.023 & -0.31 & -0.028 & -0.39 & -0.025 & -0.33 & -0.002 & -0.02 & -0.150 & -1.09 \\
\hline Fวnance & -0.154 & -1.90 & -0.140 & -1.73 & -0.148 & -1.82 & -0.145 & -1.79 & -0.114 & -1.14 & -0.181 & -1.87 \\
\hline \multicolumn{13}{|l|}{ Year dummies } \\
\hline 1996 & -0.606 & -5.32 & -0.597 & -5.25 & -0.608 & -5.33 & -0.599 & -5.24 & -0.204 & -5.18 & -0.517 & -2.61 \\
\hline 1993 & -0.879 & -4.44 & -0.926 & -4.60 & -0.923 & -4.58 & -0.923 & -4.57 & -1.010 & -4.11 & -0.976 & -3.07 \\
\hline 1998 & -0.641 & -3.68 & -0.688 & -401 & -0.672 & -3.92 & -0.674 & -3.92 & -0.875 & -4.58 & -0.613 & -2.21 \\
\hline Constant & - & - & -2.279 & -4.97 & -2.246 & -4.89 & -2.283 & -4.97 & -1.564 & -3.03 & -3.141 & -3.76 \\
\hline Number of obriervations & 2225 & & 2225 & & 2225 & & 2225 & & 1568 & & 640 & \\
\hline Wald $\gamma^{2}(a)$ & $326.62(45)$ & & 37.95 (m) & & $322.51_{c 00}$ & & $384.05_{(42)}$ & & $210.40 \mathrm{~cm}$ & & $163.17 \mathrm{~cm}$ & \\
\hline Log-Fikethood & -1153.2 & & -1155.3 & & -11540 & & -1152.3 & & -760.82 & & -3640 & \\
\hline
\end{tabular}

Nores: 1. Duration (days) in $t-1$ hhour market status (i.e employed, unemployed, OLFy10 $\mathrm{n}+\mathrm{m}$

2. Unemployment Stock d vided by the vacancy stock in travel-b-work area of residence at time $t-1$.

Probahifity of surviving self employment (SE) at time $t+1\left(S E_{n+1}-1\right)$ given selfemployed at time $t-1\left(S E_{s-1}-0\right)$ and windfall receipt at time $t$ (WF, $\left.-0 / 1\right)$. Probit esti. mates with robust standard er rons.

\subsection{Transitions into self-employment-gender decompositions}

Empirical analysis has been somewhat remiss in its analysis of female self-employment. This is unfortunate. Issues regarding discrimination, labour market segmentation, and child-care imply quite distinct occupational strategies and desires for non-standard work schedules across gender (see Casper and O'Connell, 1998; OECD, 1998; Bianchi, 2000). Therefore, to ascertain the influence of gender more fully we estimated separate male and female versions of our various Specifications - see Tables VI and VII. For brevity we display only the windfall variables and some selective variables - full regressions results are available on request.

Although not displayed in Table $\mathrm{VI}$, the receipt of a windfall per se has no influence on the probability of transition, which is related rather to the size of the windfall (Specifications $2 \mathrm{M}$ and $4 \mathrm{M}$ and Specifications $2 \mathrm{~F}$ and 4F). In contrast to Burke et al. (2002), who find no evidence of a gender differential in the relationship between inheritance and self-employment transition, our estimates suggest that the impact of a windfall is more sizeable amongst males. Our results also suggest that although wealthier males and females are more likely to enter self-employment, larger windfalls serve to reduce the probability of transition for relatively wealthier male and female respondents.

Several interesting dichotomies emerge from Table VI. Although male and female transitions emanate primarily from amongst the unemployed, female (but not male) employees are especially reluctant to transit from wage employment. Household labour income has no effect on female transitions, but is negatively related to male transitions. Moreover, whilst a degree qualification is positively associated with the probability of female transition, it has no effect on the probability of male transition. A-levels, however, exert a positive and significant (at the $10 \%$ level) effect on both male and female transitions. Turning to labour market characteristics, managerial experience is important for male respondents whereas duration (in days) at current (i.e. t-1) status only affects female respondents. Finally, male and female respondents with previous self-employment experience and male respondents whose father was self-employed, are more likely to reenter or enter self-employment respectively.

We explore gender decompositions further in Table VII by following the approach of Wunnava and Ewing $(2000)^{20}$. Specifically, we re-estimated Specifications 1-4 from Table V but this time including a variety of male/windfall interaction terms. For example, "Windfall Payment/10E+03 - Male" is a vector of interactions between windfall payments and the male dummy. Denoting the coefficients on the various windfall variables as $\beta \mathrm{wi}$ and those on the interaction terms as $\beta \mathrm{mwi}$, then $\beta \mathrm{Mwi}$ captures the male-windfall differential relative to females (as captured by $\left.\beta w_{i}\right)$, and the sum of $\left(\beta w_{i}+\beta w_{i}\right)$ represents the total windfall effect for males ${ }^{21}$.

Again, full regression results are available on request and we restrict our comments to some of the more salient findings. Windfall payments increase (at a decreasing rate) the probability of transition to selfemployment amongst both males and females, but the effect is significantly larger amongst males. Redundancy payments and inheritances increase male transitions significantly more than female transitions, whilst wealthy male recipients are significantly less likely to transit than wealthy female recipients. 


\subsection{Transitions into self-employment - labour force decomposition}

Table VIII decomposes our sample by labour force status. Given the limited number of observations on some types of windfall, and to avoid problems of multicolinearity, we were obliged to drop certain variables from our analysis. It is apparent, however, that the various windfall and interaction variables continue to exert broadly the same effects on the probability of transition as found previously. There are some findings peculiar to a particular status. Wealth has a positive effect on the probability of employees moving into selfemployment, but no effect on unemployed or non-participating respondents. Conversely, household income retards only the transition of employees into self-employment. Moreover, whilst previous self-employment experience is a valuable asset for all labour force categories, previous managerial experience enhances the transition from paid employment only. And finally, the probability of transition significantly declines with the duration of a current spell spent either unemployed or out of the labour force.

\subsection{Self-employment survival}

We turn our attention in Table IX to the issue of self-employment survival vis. the probability of a respondent being self-employed at time $t+1$ given that the he was self-employed at time $t-1$. Windfall receipts are again recorded at $t$. Some interesting dichotomies are apparent. There is tentative evidence that survival decreases with the size of a windfall (Specification 2S), especially if the windfall is in the form of an inheritance. A lottery win, however, raises the probability of survival, particularly amongst males.

These findings accord with Taylor (2001) and ". . suggest that the self-employed, once their business is established, do not suffer from liquidity constraints seriously enough for their survival to be threatened." (Taylor, 2001, p. 552]. There is, however, the alternative explanation that the receipt of a windfall affects equally survival in, and withdrawal from, self-employment. As noted earlier, a windfall may accelerate labour market withdrawal (see, for example, Holtz-Eakin et al. (1993)]. Thus for some individuals, an inheritance may increase the utility stemming from other labour market states (such as early retirement) and render selfemployment exit the utility-maximising option. This line of argument is supported by the findings that less whilst less wealthy respondents are more likely to survive in self-employment, wealthier windfall recipients are more likely to exit self-employment.

A number of other important effects emerge. Males are more likely to remain in self-employment, while those with children or with a health problem that limits the type and/or amount of work they are able to do, are less likely to survive. Consistent with Cressy (1996) and Taylor (1999), age is significantly linked to the probability of survival amongst both males and females. In terms of education, degree qualifications enhance the probability of female survival, whereas "other qualifications" are important for males. These findings accord with Cowling and Taylor (2001), who argue that the success of highly educated women in self-employment reflects their increased self-assurance and, perhaps, ability to with stand any gender discrimination. For males, on the other hand, non-academic factors, such as life experience and social capital, are the key determinants of entrepreneurship.

Intergenerational links play a less important role in the survival of a self-employed business than in its creation. This result is less extreme than Taylor (1999) who finds that a self-employed parent has no effect on the probability of exit. Taylor's finding is surprising as one would expect individuals with self-employed parents to have inherited at least some business acumen (Lentz and Laband, 1990).

Self-employed employers are more likely to survive than own-account workers, whilst professional, managerial, and skilled manual workers are more likely to survive than unskilled manual workers. Consistent with Jovanovic (1982), there is evidence of duration dependence with the probability of survival across both genders, but especially amongst males, increasing with the duration of self-employment. Somewhat surprisingly, males who have experienced self-employment before are less likely to survive. This could indicate a lack of entrepreneurial ability and business acumen, or perhaps a stubborn and misguided obstinacy on their part. 


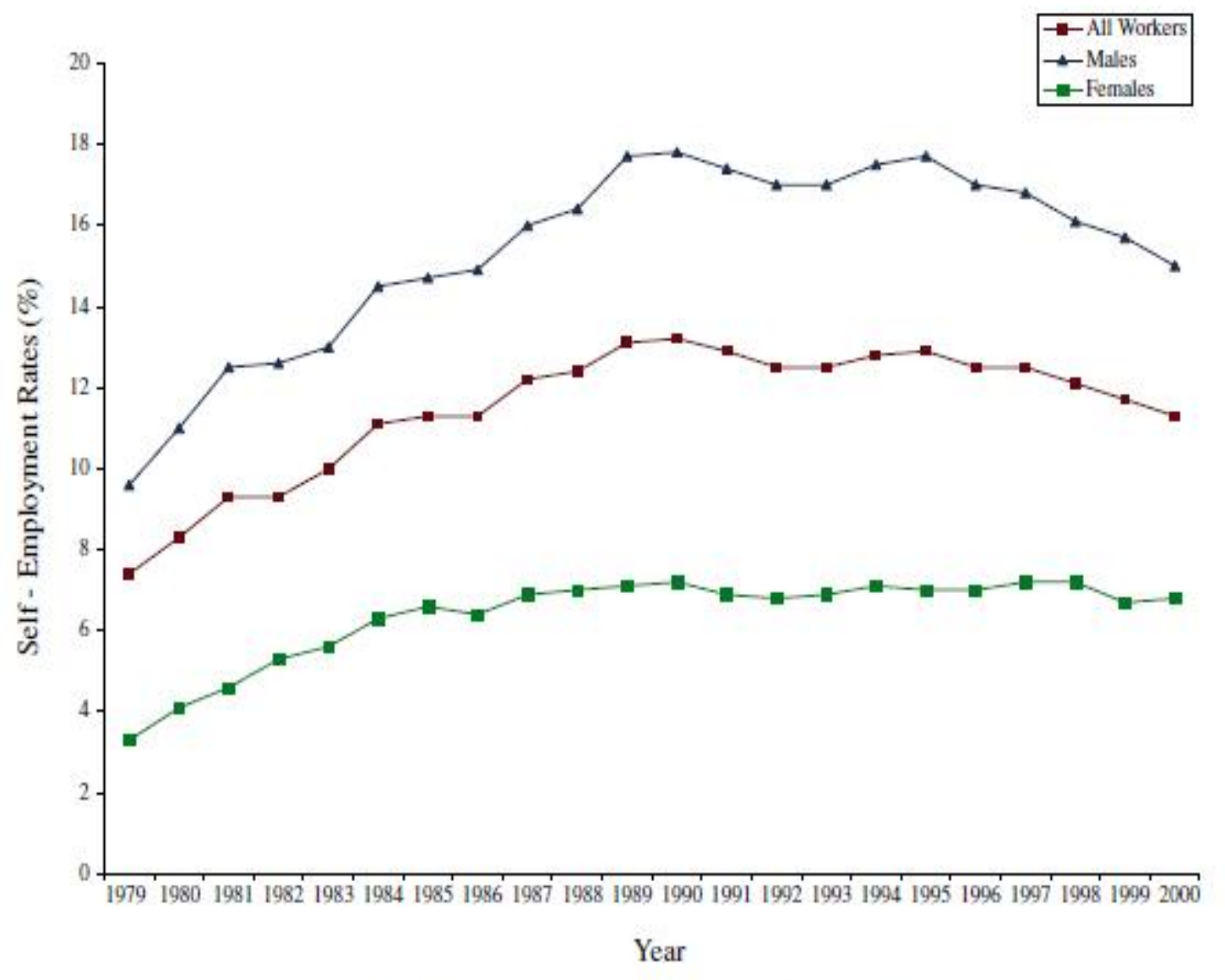

Figure 1. British Self-employment rates ${ }^{22}$ 1979-2000.

Source: Economic Trends Annual Supplement 2001, Office for National Statistics.

Although they had no affect on transitions into self-employment, high unemployment/vacancy ratios reduce the probability of survival, implying that self-employment rates will be affected by economic recessions. Industry effects are also apparent. Relative to the omitted category "other industry" (primarily individuals who are specialising in non-financial services), proprietors in agriculture and construction are especially likely to survive in self-employment, and those in manufacturing and finance are especially likely to fail. Finally, time effects are apparent with the probability of exiting peaking in 1997. This accords with Figure 1, which illustrates a clear slump in the level of self-employment in the late 1990s.

\section{FINAL COMMENTS}

In this paper we have examined the birth and death of entrepreneurial activity amongst a representative sample of British workers. To be precise, we have used data from the BHPS to identify factors at time t-1 that play a pivotal role in the transition to, and survival in, self-employment at times $t+1$ and, to a lesser extent, $t+2$. In particular, we have focused on the role of windfall payments. These are an excellent proxy for the presence of liquidity constraints, being uncorrelated with the presence of any pre-transitional entrepreneurial ability or acumen.

Our results suggest the presence of significant capital constraints. Wealthier individuals are more likely to transit ceteris paribus, whilst windfalls raise the probability of transition at a decreasing rate - gains or more than $£ 20000-£ 22000$ reduce the probability of transition whilst those of more than $£ 90000-£ 100000$ imply a negative transition rate. Moreover, larger windfalls reduce the probability of relatively wealthier respondents 
making a transition to self-employment. These findings support earlier work by Evans and Jovanovic (1989), Evans and Leighton (1989), Holtz-Eakin et al. (1994a), Blanchflower and Oswald (1998), and Burke et al. (2000, 2002).

We also find peculiarities in the effects of particular types of windfall. Redundancy payments and inheritances raise the probability of transition, whilst lottery wins reduce the probability of (especially male) transitions. In contrast, inheritances (lottery wins) hinder (augment) self-employment survival. Our results also allude to significant differences in the factors that affect the propensity of males and females to become and survive as entrepreneurs. Whilst male and female transitions tend to emanate from amongst the unemployed, females appear particularly reluctant to leave paid employment. Further gender differentials are apparent across education, tenure, and the effect of household income.

To conclude, our results offer significant support for the liquidity constraints hypothesis, but also highlight the sensitivity of the relationship between capital and entrepreneurship. There is evidence of a strong income effect, with sufficiently large capital receipts inducing individuals - particularly wealthy ones - to shy away from self-employment. In terms of policy, our results suggest that entrepreneurial "start-up" funds should be very precisely targeted, in terms of both their size and intended recipients.

\section{Acknowledgements}

We are grateful to the ESRC Data Archive for supplying the British Household Panel Study Survey, and to three anonymous referees and the editors of this journal for helpful comments.

\section{ENDNOTES ENDNOTES}

\section{ENDNOTES}

1 The Australian "New Enterprise Incentive Scheme", for example, provides training and income support to unemployed individuals who wish to enter self-employment. Similarly, the UK government provides transfer payments to the unemployed whilst they start their business, whilst in the US a number of schemes have emerged to encourage the growth of minority small business (see Le, 1999).

2 Similarly, Blanchflower and Oswald (1998) report that more than half of those respondents in the British Social Attitudes Survey who were seriously considering self-employment had not made the transition due to an inability to raise the requisite capital.

${ }^{3}$ We define a windfall gain as an unanticipated increase in the respondent's capital - for example, a lottery win.

${ }^{4}$ Moreover, if potential entrepreneurs accumulate the requisite capital in anticipation of self-employment, then a positive correlation between wealth and entrepreneurial ability would not be surprising (see Xu, 1998).

${ }^{5}$ Cressy's (1999) results are in line with those of Cowling and Mitchell (1997) who find that the employment related human capital, captured by industrial and business experience, plays an important role in determining the exit rate from selfemployment to employment.

${ }^{6}$ Because layoffs in the UK tend to be permanent, the Redundancy Payments Act (1965) requires employers to compensate workers so affected.

${ }^{7}$ For a theoretical analysis of the possible endogeneity of wealth see Xu (1998).

${ }^{8}$ As Taylor (2001) concedes, although self-assessment removes the formal problem of defining self-employment, there may be discrepancies across individuals in how self-employment is defined.

${ }^{9}$ Note that the categories of payment in Table III are not mutually exclusive - it is possible for a respondent to record the receipt of more than one windfall payment type. 
${ }^{10}$ Recent empirical evidence suggests that UK transitions into self-employment are male dominated - see Curran and Burrows (1989), Campbell and Daly (1992), Abell et al. (1994), Le (1999), and Figure 1. However, although a larger proportion (measured as a percentage of workforce) of men are self-employed, the proportionate increase in self-employment over the last two decades has actually been greater for women (Taylor, 1997).

${ }^{11}$ An alternative to the binary specification is the multinomial logistic approach. Although this would enable us to explore the relationship between self-employment and other labour market states, it is thwarted in our data by the problem of small cell sizes.

${ }^{12}$ The distribution of the "Income from Dividends and Interests" data gave rise to choosing $£ 2500$ as the appropriate separation. Experimentation with other separation values did not substantively alter the results.

${ }^{13}$ Non-recipients are recorded as having received a zero value windfall. Specifications 2-4 suggest that the probability of transition is maximised at windfall values between $£ 20000$ and $£ 22000$. Higher order polynomials of the windfall were found to be insignificant. Following Taylor (2001), a series of dummy variables measuring the amount received were also tried. The results implied a very similar non-linear relationship, with a higher probability of entering self-employment if a windfall payment is in the region between $£ 5000$, and $£ 15000$, and a lower probability if a payment exceeds $£ 15000$. The reported specifications were chosen on the basis of log-likelihood comparisons.

${ }^{14}$ According to Taylor (2001) there is another explanation for this relationship. Given that self-employment is riskier than wage employment and that individuals are generally risk-averse, then ". . .decreasing absolute risk-aversion will mean that the probability of entering self-employment will be increasing in assets. To test between these hypotheses requires explicit measures of risk aversion, which are difficult to obtain in general purpose surveys." (Taylor, 2001, p. 563, footnote 22).

${ }^{15}$ The types of windfall payment received are jointly significant at $1 \%$ level.

${ }^{16}$ We also experimented with the respondent's pre-transition wealth via a six point scale - Annual Income from Dividends and Interest equal to $£ 0$, £1-£999, £1000-£2500, £2501-£5000, £5001-£10000, and $>£ 10000$. The results showed that the probability of transition increases with wealth, the three latter categories being positive and significant. Interacting these categories with windfall gains yielded negative and significant interaction terms, thereby affirming the results presented in the paper. The reported specifications were, again, chosen on the basis of log-likelihood comparisons.

17 The age range 18-60 ensures the inclusion of all age categories and excludes (at least to an extent) the retirement effect. Following the practice of other studies we also include a quadratic term so as to allow for non-linearities.

${ }^{18}$ Education refers to the highest qualification held by the respondent. 'Degree' denotes a University first degree or equivalent; 'A Level' denotes the Advanced Level university entrance-level qualification, typically taken at age 18; 'O-level' denotes the Ordinary Level qualification typically taken at age 16 at the end of compulsory schooling.

${ }^{19}$ The null hypothesis of 'no regional effects' is decisively rejected by a Likelihood Ratio (LR) Test $\left[\chi^{2}(7,0.01)=27.21\right]$

${ }^{20}$ We thank an anonymous referee for suggesting this approach.

${ }^{21}$ To avoid the problem of multicolinearity, the 'pure' male dummy variable is omitted from the specification.

${ }^{22}$ Self-employment rates are defined as the number in self-employment as a percentage of all individuals in employment.

\section{REFERENCES}

Abel P., P. Crouchley and D. Smeaton 1994, 'An Aggregate Time-Series Analysis of Non-Agricultural Self-Employment in the UK', London School of Economics, Centre for Economic Performance, Discussion Paper, No. 209.

Bates, T., 1990, 'Entrepreneur Human Capital Inputs and Small Business Longevity', The Review of Economics and Statistics 72(4), 551-559.

Bernhardt, I. 1994, 'Comparative Advantage in Self-Employment and Paid Work', Canadian Journal of Economics 27 (Issue 2), 273-289.

Black, J., D. de Meza and D. Jeffreys, 1996, 'House Prices, The Supply of Collateral and The Enterprise Economy', Economic Journal 106, 60-75. 
Blanchflower, D. and A. J. Oswald, 1998, 'What Makes an Entrepreneur?', Journal of Labor Economics 16, $26-60$.

Bianchi, S. M., 2000, 'Maternal Employment and Time with Children: Dramatic Change or Surprising Continuity', Demography $37,401-414$.

Bruce, J., 1999, 'Do Husbands Matter? Married Women Entering Self-Employment', Small Business Economics 13(4), 317-329.

Burke, A., E., F. R. Fitzroy and M. A. Nolan, 2000, 'When Less is More: Distinguishing Between Entrepreneurial Choice and Performance', Oxford Bulletin of Economics and Statistics 62(5), 565-587.

Burke, A., E., F. R. Fitzroy and M. A. Nolan, 2002, 'Self-Employment, Wealth and Job Creation: The Role of Gender, NonPecuniary Motivation and Entrepreneurial Ability', Small Business Economics 19(3), 255-270.

Campbell, M. and M. Daly, 1992, 'Self-Employment: Into the 1990s', Employment Gazette 100(6), 269-292.

Caputo, K. and A. Dolinsky, 1998, 'Women's Choice to Pursue Self-Employment: The Role of Financial and Human Capital of Household Members', Journal of Small Business Management 36(3), 8-17.

Casper, L. M. and M. O'Connell. 1998, 'Work, Income, the Economy, and Married Fathers as Child-Care Providers', Demography 35, 243-250.

Coate, S. and S. Tennyson, 1992, 'Labour Market Discrimination, Imperfect Information and Self-Employment', Oxford Economic Papers 44, 272-288.

Cowling, M. and P. Mitchell, 1997, 'The Evolution of the UK Self-Employment: A Study of Government Policy and the Role of the Macroeconomy', The Manchester School 65(4), 427-442.

Cowling, M. and M. P. Taylor, 2001, 'Entrepreneurial Men and Women? Two Different Species?', Journal of Small Business Economics 16(3), pp. 167-175.

Cressy, R., 1996, 'Are Business Start-ups Debt-Rationed?', The Economic Journal 106, 1253-1270.

Curran, J. and R. Burrows, 1989, 'National Profiles of the Self-Employed', Employment Gazette 97(7), 376-386.

De Wit, G. and A. M. Van Winden, 1990, 'Empirical Analysis of Self-employment in the Netherlands', Economics Letters 32, 97100.

Dunn, T. and D. Holtz-Eakin, 2000, 'Financial Capital, Human Capital, and the Transition to Self-Employment: Evidence from Intergenerational Links', Journal of Labor Economics 18, 282-305.

Evans, D. and B. Jovanovic, 1989, 'An Estimated Model of Entrepreneurial Choice under Liquidity Constraints', Journal of Political Economy 97, 808-827.

Evans, D. and L. S. Leighton, 1989, 'Some Empirical Aspects of Entrepreneurship', American Economic Review 79, 519-535.

Fairlie, R. W., 1999, 'The Absence of the African-American Owned Business: An Analysis of the Dynamics of Self-Employment', Journal of Labour Economics 17(1), 80-108.

Georgellis, Y., J. G. Sessions and N. Tsitsianis, 2003, 'Self-Employment Dynamics: A Review of the Literature', Working Paper: Department of Economics and International Development, University of Bath.

Holtz-Eakin, D., D. Joulfaian and H. Rosen, 1994a, 'Sticking it Out: Entrepreneurial Survival and Liquidity Constraints', Journal of Political Economy 10(2), 53-75.

Holtz-Eakin, D., D. Joulfaian and H. Rosen, 1994b, 'Entrepreneurial Decisions and Liquidity Constraints', Rand Journal of Economics 25, 334-347.

Holtz-Eakin, D., D. Joulfaian and H. S. Rosen, 1993, 'The Carnegie Conjecture: Some Empirical Evidence', Quarterly Journal of Economics 108(2), 413-435.

Hughes, K., M. A. Bellis and M. Kilfoyle-Carrington, 2001, 'Alcohol, Tobacco and Drugs in the North-West of England: Identifying a Shared Agenda', Public Health Sector, Liverpool John Moores University.

Johansson, E. 2000, 'Self-Employment and Liquidity Constraints: Evidence from Finland', Scandinavian Journal of Economics $102,123-134$.

Jovanovic, B. 1982, 'Selection and the Evolution of Industry', Econometrica 50, 649-670.

Kidd, M. P. 1993, 'Immigrant Wage Differentials and the Role of Self-Employment in Australia', Australian Economic Papers 32(60), 92-115. 
Le, A.-T. 1999, 'Empirical Studies of Self-employment', Journal of Economic Surveys 13(4), 381-416.

Lentz, B. F. and D. N. Laband, 1990, 'Entrepreneurial Success and Occupational Inheritance among Proprietors', Canadian Journal of Economics 23(3), 230-245.

Lindh, T. and H. Ohlsson, 1996, 'Self-Employment and Windfall Gains: Evidence from the Swedish Lottery', Economic Journal 106, 1515-1526.

Meyer, B. 1990, 'Why Are There So Few Black Entrepreneurs?', National Bureau of Economic Research, Working Paper, No. 3537.

OECD, 1998, Women Entrepreneurs in Small and Medium Business, Paris and Washington DC: OECD.

Pfann, G. A, 2001, ‘Downsizing'. IZA Discussion Paper, No. 307.

Schmitz, J. A., 1989, 'Imitation, Entrepreneurship and Long Term Growth’, Journal of Political Economy 97, 721-739.

Stiglitz, J. E. and A. Weiss, 1981, 'Credit Rationing in Markets with Imperfect Information', American Economic Review 71, 393410.

Taylor, M., 1997, 'The Changing Picture of Self-Employment in Britain', Institute of Labour Research, ESRC Research Centre on Micro-Social Change, University of Essex, Paper No. 97-9.

Taylor, M., 1999, 'Survival of the Fittest? An Analysis of Self-Employment Duration in Britain', Economic Journal 109, $140-155$.

Taylor, M., 2001, 'Self Employment and Windfall Gains in Britain: Evidence from Panel Data', Economica 68(272), 539-565.

Waller, S. and M. Lyons, 2001, 'The Debate Gets High', North West Health Bulletin 2(2), 34-45.

Wunnnava, P. V. and B. T Ewing, 2000, 'Union-Nonunion Gender Wage and Benefit Differentials across Establishment Sizes', Journal of Small Business Economics 15(1), 47-57.

Xu, B., 1998, 'A Re-Estimation of the Evans and Jovanovic Entrepreneurial Choice Model', Economics Letters 58, 91-95. 
